\title{
Earthquakes and terrorism: the long lasting effect of seismic shocks ${ }^{1}$
}

\author{
José G. Montalvo \\ UPF-BarcelonaGSE-IPEG \\ Marta Reynal-Querol \\ UPF-ICREA-BarcelonaGSE-IPEG
}

\begin{abstract}
${ }^{1}$ We appreciate the comments of Martin Feldstein, Kai Konrad, and participants in the NBER Summer Institute on the "Economics of National Security", the Conference on Advances on the Political Economy of Conflict and Redistribution III, the Paris School of Economics and the HiCN Annual Workshop at UC Berkeley. We acknowledge the excellent research assistance provided by Juan Carlos Muñoz, Paula Garda, Marian Meller and Ece Yagman. Financial support from the European Research Council under the European Community ERC Grant Agreement n.647514, the Spanish National Science Foundation ECO2014-5555-P, and the Government of Catalonia (ICREA) is gratefully acknowledged. We are also thankful for the financial support provided by the Spanish Ministry of Economy and Competitiveness, through the Severo Ochoa Programme for Centres of Excellence in R\&D (SEV-2015-0563).
\end{abstract}




\begin{abstract}
The literature on the effect of shocks on civil conflicts has grown rapidly over the last decade. In this paper, we study the relationship between earthquakes and terrorism. Medium intensity earthquakes can produce an inadequate response on the part of the government and generate, or exacerbate, previous grievances perceived by the population of the affected area. Since destruction of infrastructures in these cases would be limited, the state keeps most of its coercive capacity, which reduces the chances of full-fledged conflict but leaves open the possibility of low intensity rebellious acts such as terrorism. We propose a new algorithm to classify terrorism events as domestic or transnational, and we show that the likelihood of a domestic terrorist events increases with the previous occurrence of an earthquake. Using earthquakes as an instrument for income, we also show that development has a positive and significant effect on the likelihood of terrorist events.
\end{abstract}

Keywords: Local terrorism, earthquakes, persistence

JEL classification: H56, O15 


\section{Introduction}

The last few years have seen a growing number of analyses relating shocks, mostly natural disasters and climatology (e.g., rainfall, temperature, windstorms, etc.), to economic outcomes, democratization, political transitions, or violent conflicts. The exogenous nature of these events helps in the identification of its effects on a given spatial area. In other instances these variables are used as instruments to analyze the transmission mechanism of other relevant variables, primarily income. This literature has evolved towards the use of panel data or increasingly smaller geographical areas.

Recent papers have also examined not only the short-run impact of such idiosyncratic shocks but also the long-run consequences. In some cases, the propagation mechanism is institutional inertia. Dell (2012) argues that drought severity during the time of the Mexican revolution affected longrun economic performance through differences in the intensity of insurgency across Mexican regions and the effects of the latter on a land institution called "ejido" [1. Belloc et al. (2016) claim that earthquakes decrease the probability of shifts from a feudal regime to communal institutions and, through institutional inertia, potentially affect economic development in the long run. Other times the persistence of the impact of a natural disaster is channeled through a technological development. Hornbeck \& Naidu (2014), for example, show that the 1927 Mississippi flood produced a large and persistent out-migration of African-Americans that led to an increase in the capital intensity of agricultural activities of flooded counties, spurring economic development. The extent of the impact of natural disasters can also vary in terms of the adoption of new technologies. Using yearly data between 1470 and 1990, Jia (2014) finds that while droughts increased the probability of peasant revolts in China, the integration of sweet potatoes (i.e., the new technology) dampened the effects of these shocks on conflict. In other cases, the long-run effect is explained by the permanent nature of the shock. Hornbeck (2012) analyzes the long-run effect of large dust storms in the US during the 1930s. Significant erosion of the topsoil produced a reduction in agricultural productivity lasting many decades after the storms.

In this paper, we aim to understand the long-run impact of earthquakes on domestic terrorism. To this end, we conduct a geographically detailed empirical analysis, at the subnational level, for all countries in the world over the period 1994-2007. Our units of observation are grids defined as $120 \mathrm{~km}$ $\mathrm{x} 120 \mathrm{~km}$ cells. This unit of analysis covers the intersection of pixels generated by a high resolution grid and countries, defined as a pixel-country 
cell (henceforth, cell). To date, the empirical literature on terrorism has largely relied on cross-country data. Moreover, and with very few exceptions (e.g., Enders et al. (2011), Piazza (2011), Choi \& Piazza (2016), and Enders et al. (2016)), previous studies have predominately analyzed international terrorism. Research on the quantitative study of transnational terrorism includes the work of Sandler et al. (1983), Im et al. (1987), Enders et al. (1992), and Enders \& Sandler (1993, 1999), among others. More recent work includes Krueger \& Laitin (2008), Krueger \& Maleckova (2002), Piazza (2006), Abadie \& Gardeazabal (2008), Keefer \& Loayza (2008), and Savun $\&$ Phillips (2009). An important motive for their focus on international terrorism is data availability. Enders et al. (2011) pioneer a new method to identify transnational versus domestic terrorist events based on the Global Terrorism Database (GTD). Piazza (2011), using this data, revisits the relationship between poverty and terrorism and suggests that minority economic discrimination is an important factor in explaining domestic terrorism.

Our analysis presents four novelties with respect to the previous literature on the causes of terrorism. First, while much research focuses on international terrorism, we analyze domestic terrorism ${ }^{2}$. It is well known that international terrorism represents only a small and decreasing part of all terrorist events (Sandler, 2014). Moreover, the causes of domestic and international terrorism may be quite different (Sandler, 2014). Given that many studies at the cross-country level use only international events to infer the general determinants of terrorism, this paper helps to better understand the differential determinants of both types of terrorism. To this end, we present a new working definition of domestic terrorism ${ }^{3}$ so as to separate the latter from international terrorism in the Global Terrorism Database (GTD), using information on the profiles and biographies of the perpetrator groups. This material, taken together with different definitions of "domestic terrorist event," allow us to distinguish domestic from international events for the period 1970 to 2007 for all countries in the world affected by terrorism. We also compare our data with that resulting from the methodology of Enders et al. (2011), to further distinguish between domestic and international events.

Second, we locate the specific geographical location of each terrorist event. Although many terrorist organizations have a local origin, most of the literature on the causes of terrorism is based on country-level data ${ }^{4}$. While it may make sense to use countries as a unit of observation in studies on international conflict, where the state is assumed to be a unitary actor, domestic terrorism involves at least two actors within the boundaries of a stat 5 . Neglecting within-country variation may distort the interpretation of the determinants of domestic terrorism. We therefore aim to analyze the local determinants of 
terrorism so as to uncover space-varying features that contribute to explaining terrorism on a subnational level. To this end we conduct a geographically detailed empirical analysis the period 1994-2007. Our units of observation are cells resulting from superimposing a $1^{\circ} \times 1^{\circ}$ grid on the map of the world. This grid approach, or the use of very geographically disaggregated units of analysis, is now a relatively common strategy in economic research ${ }^{6}$. The coordinate system is, at least to a first approximation, statistically independent of economic data, and the units are of nearly uniform size. We define our final units of observation as a pixel-country cell since institutional factors are likely to be important for explaining terrorism. Moreover, using cells without reference to particular countries would prevent the use of national institutions as statistical determinants 7 .

Our third contribution is the use of pixel-country cells as the basic unit of observation. Recent analyses using geocoded attack locations and cells from a grid that covers the terrestrial areas of the world employ, for the most part, a common resolution for all the cells. Several recent papers use the PRIOGRID dataset, which is released with a $0.5 \times 0.5$ decimal degree of resolution, to study the determinants of conflict at the subnational level or to merge the set of explanatory variables at the cell level with other databases. Working with a fixed cell size is convenient because it allows for the use of ready-made databases at the subnational level, such as the aforementioned PRIO-GRID ( $0.5^{\circ}$ latitude $\times 0.5^{\circ}$ longitude) or the G-Econ ( $1^{\circ}$ latitude $\times 1^{\circ}$ longitude) project at Yale University. However, for the purposes of our paper, fixed-size cells are inconvenient because they do not control for country borders. We instead aim to characterize the local determinants of terrorism by analyzing within country variation. This requires the ability to control by institutional characteristics of the respective countries as the latter differently affect the likelihood of terrorist attacks in different countries. We therefore need to break down regular size cells that are spread across one or more countries. For instance, in Africa there are around 2,400 $1^{\circ} \times 1^{\circ}$ cells but close to 3,500 pixel-country cells starting at the $1^{\circ} \times 1^{\circ}$ resolution. As there are common institutional factors within each country, we also include fixed effects to control for the latter and analyze purely within country variation. Again, for this purpose, we need to work with pixel-country cells. Notice that this new subnational level unit requires the recalculation of all the variables at this level of resolution as the standard databases are only usable for regularsize cells.

Finally, we analyze the effect of the level of development on the likelihood of terrorism. There has long been debate over this issue. Most of the literature finds no effect of poverty, or development, on terrorism at the country level. 
However, at that level of aggregation it is difficult to disentangle the effect of development on terrorism because the process can go either direction, generating an important endogeneity problem. By disaggregating domestic and transnational terrorist incidents and time series, Enders et al. (2016) establish a robust nonlinear relationship between income and terrorism. More specifically, they decompose transnational terrorism by distinguishing between the location of the attack and the perpetuators' home country. When the focus is on the latter, they find a stronger connection between low per capita income and transnational terrorism ${ }^{8}$. Nemeth et al. (2014) find, using subnational cells, a negative effect of gross cellular product on terrorism. In contrast with this finding, using individual data on terrorists, Krueger \& Maleckova (2002) show that terrorists have a higher than average level of education.

Geographic disaggregation is particularly important when studying the role of economic shocks, as some of the effects of such shocks on the likelihood of terrorist attacks will be localized. Angrist \& Kugler (2008), for example, show that in areas of Colombia where coca cultivation increased violence also increased. Dube \& Vargas (2013) show that the sharp fall in coffee prices in Colombia lowered wages and increased violence mostly in municipalities where coffee was the predominant source of income. Harari \& La Ferrara (2013) also use very small areas (at the cell level) to analyze the role of climate change on conflict ${ }^{9}$. They argue that the effect may be quite localized since rain, temperature, and the evaporation index depend crucially on the type of soil and its ability to retain water. Their multi-scalar drought index changes significantly according to different areas within each country. There is also important variance within countries in terms of topographic characteristics such as elevation or roughness of the terrain. Ciccone (2008) similarly concludes that uncovering the effect of precipitation on the risk of conflict requires more than cross-country disaggregated data.

Theoretically, the effect of economic shocks on conflict is ambiguous: on the one hand a negative shock to the local economy decreases the opportunity cost of participating in armed conflicts. On the other hand, a reduction in lootable resources also diminishes incentives to participate in insurgent groups as the reward is also reduced ${ }^{10}$. Chassang \& Padro-i Miquel (2009) develop a bargaining model that shows that the opportunity cost of conflict is a weak explanation for the correlation between conflict and level of income per capita. However, they also show that the opportunity cost can explain why civil wars happen after negative economic shocks.

If variance in level of development hides structural differences, it is therefore important to investigate the causes of such differences. Among several 
alternative mechanisms, the recent literature 11 explains the risk of conflict or terrorist acts based on the role of infrastructures and state capacity. The first channel is through state capacity to collect tax revenues. A negative economic shock reduces the latter and, therefore, the ability of the government to repress terrorist actions. Moreover, a shock that affects the ability of infrastructures to fulfill their functions may also make it more difficult to catch the terrorists.

To the extent that choice of location is critical to terrorist groups' survivability, Gaibulloev (2014) points out that government instability and the risk of state failure are strong predictors of terrorist presence. Another major determinant of location choice is the existence of other terrorist groups, as the entrants can benefit from both the diffusion of knowledge and dwindled government counter-terrorism capacity. Gaibulloev (2014) shows that the existence of ideologically similar terrorist groups increases the probability that a new terrorist group will chose the same home base. The latter also offers an available social infrastructure, allowing terrorists to act and disappear before being captured. For instance, two-thirds of the victims of the terrorist group ETA were killed in the Basque Country, a small area of the Spanish territory, despite the fact that ETA's objective is independence from Spain. Many of these murders took place in towns where political support of the terrorist group was strong and had ample popular backing $\frac{12}{2}$. In such a situation, a good physical infrastructure does not necessarily act as a strong enough deterrence device because the social infrastructure supporting the terrorists $\$ 13$ counterbalances the benefits of apparently good logistics. In the case of the Basque Country, the roughness of the terrain and the altitude of some of the mountains also facilitates terrorists' ability to escape $\mathrm{e}^{14}$.

There are thus both theoretical and empirical reasons that encourage the use of high-level geographical disaggregation in the study of terrorist acts. Finally, and in contrast with other studies on the interaction between shocks and violence, we consider countries throughout the world as opposed to Africa alone, although we also check the robustness of the results using only cells in African countries.

The literature on the effect of shocks on civil conflicts has grown rapidly over the last decade. A strand of this line of research emphasizes the effect of climate shocks on violence, political/leader transition, or political instability 15 . Several papers argue that the transmission mechanism of such shocks is channeled through climate-induced changes in income, although this remains a matter of debate. Most of the research on shocks and violence concerns climate shocks (e.g., abnormal temperatures, extreme rainfall episodes, etc.) 
although there are also examples relating natural disasters like earthquakes to civil conflict, political transitions, and terrorism. Brancati (2007) shows, using cross-country data, that earthquakes increase the likelihood of conflict $\frac{16}{16}$. Habibur Rahman et al. (2017) claim that earthquakes open a window of opportunity for political transition. The extent of this window depends on the rate of economic recovery after the shock. Berrebi \& Ostwald (2011) identify a strong and positive impact of natural disasters on terrorism with a varying level of intensity along GDP per capita and type of disaster (e.g., geophysical vs. climatological).

In this paper we present evidence of the relationship between earthquakes and terrorism. We find empirical evidence of this connection even many years after the occurrence of the earthquake, although its influence on domestic terrorist acts declines over time. Brancati (2007) similarly shows that very high intensity earthquakes produce a large increase in the probability of civil wars. Medium to high intensity earthquakes do not, however, seem to have such a strong effect, although they may produce an inadequate response from the government and generate, or exacerbate, previous grievances of the population in the affected area. An earthquake can also increase the salience of these grievances should government reaction in helping the poor, or a particular ethnic/religious/social group, be perceived as slower/weaker than that provided to other groups. As the destruction of infrastructures would be limited in most cases, the state will keep its coercive capacity, reducing the chances of a full-fledged conflict but leaving open the possibility of low-intensity rebellious acts such as terrorism. If the recovery of economic activity $\sqrt{17}$ is fast, then the opportunity cost of rebellion will quickly decrease. In this case, economic conditions may recover, but resentment towards authorities will remain long after the occurrence of the earthquake.

The remainder of this article is organized as follows. Section 2 presents the data and, specifically, the construction of the geo-referenced data on terrorist events. Section 3 shares the econometric specification and the main results. Section 4 provides the analysis of the relationship between terrorism and income using seismic events as an instrumental variable. Finally, section 5 concludes. 


\section{Data}

\subsection{Sources of data on terrorism}

One of the most authoritative sources of data on terrorism is the "Patterns of Global Terrorism" report, prepared by the US State Department. This report provides information, for each country, on "acts of international terrorism," defined as "terrorism involving citizens or the territory of more than one country" (United States Department, 2004). The report defines transnational terrorism as: "Premeditated politically motivated violence, perpetrated against non-combatant targets by subnational groups or clandestine agents, usually intended to influence an audience." Perhaps the most significant study that uses this data is that of Krueger \& Laitin (2008), who analyze the economic causes of international terrorism.

The second authoritative data source on transnational terrorism is ITERATE (International Terrorism: Attributes of Terrorism Events), constructed by Mickolus (1980, 1982) and Mickolus et al. (1989). An updated version is used by Enders \& Sandler (2000). ITERATE relies on the world's print news and electronic media for its data, with particular reliance on the Foreign Broadcast Information Service (FBIS) Daily Reports, which surveys hundreds of the world's newspapers and related sources. These data measure the number of international terrorist attacks occurring in each country. Terrorism is defined as "the premeditated use, or threat of use, of extra-normal violence or brutality to gain a political objective through intimidation or fear of a targeted audience".

Yet another source of data on terrorism, although not as popular those already mentioned, is the dataset provided by the Memorial Institute of Prevention of Terrorism (MIPT). This dataset provides information on international terrorism from 1972 to 2006. The total number of incidents reported is 31,662 . While this is the only database that distinguishes between domestic and international terrorism, it only does so from 1998 to 2006 . In contrast to international terrorism, domestic terrorism instead refers to events where the country of origin of the perpetrator group is the same as the target country, or target nationalities. Sambanis (2008) uses this dataset to analyze the causes of domestic terrorism events between 1998 and 2003, using a cross-section of countries. He also endeavors to distinguish domestic cases using the data of Krueger \& Laitin (2008), analyzing only the events in which the place of the attack was the same as the country of the perpetrator and at least one of the two countries that were most affected by the attack. One issue, 
however, is that the data used by Krueger \& Laitin (2008) (from Patterns of Global Terrorism), does not explicitly include the domestic events, such that Sambanis (2008) likely only captures very few cases. Such as, for example, where a group from country A attacks a US Embassy, but also kills people from country A. It is, in fact, quite difficult for Sambanis (2008) to capture domestic events when using the data from Patterns of Global Terrorism as this source only provides information on transnational terrorist events.

Abadie (2006) argue that studies that use data on transnational terrorism based on either Patterns of Global Terrorism or other sources, "suffer, in principle from some important shortcomings. First of all, the US State Department data (Patterns of Global Terrorism dataset) cover only events of international terrorism, that is, those that involve citizens or property of more than one country. However, international terrorism represents only a small fraction of terrorist activity. For example for the year 2003, the MIPT terrorism knowledge base reports 1,536 events of domestic terrorism, but only 240 events of international terrorism" 18 . Abadie (2006) also suggest that the causes of international terrorism may differ from those of domestic terrorism, and therefore the policy implications could be very different. He use a new dataset on the intensity of country-level terrorist risk using information from an international risk rating agency. In particular, the authors use the World Market Research Center's Global Terrorism Index (WMRC-GTI). The WMRC-GTI assesses the risk of terrorism in 186 countries and against these countries' interests abroad for the period 2003/4. The WMRC-GTI includes five factors forecasting motivation, presence, scale, efficacy, and prevention of terrorism. As Abadie (2006) argue, "terrorist risk ratings have obvious limitations. They provide only a summary of an intrinsically complex phenomenon." However, they notice that these risk rating "incorporate information that relate to risk but are not reflected in casualties". This was indeed an advantage, as the data on terrorist events available up until their article considered only transnational cases.

There is, to date, no comprehensive dataset on domestic terrorism, and consequently no comprehensive study that analyzes whether the latter has different determinants than international terrorism. It is clear, however, that studies on international terrorism and its implications cannot be applied directly to domestic terrorism. For the purpose of analyzing domestic terrorism, we must therefore construct a dataset that separately identifies the two. Below we describe our new dataset on terrorist events that facilitates this distinction.

We use the Global Terrorism Database (GTD), an open-source database 
which provides information on all terrorist events around the world from 1970 through 2016. Unlike many other event databases, the GTD includes systematic data on domestic as well as international terrorist incidents that have occurred during this time period, for a total of more than 170,000 cases. The GTD was developed to be a comprehensive, methodologically robust set of longitudinal data and is currently maintained and provided by the National Consortium for the Study of Terrorism and Responses to Terrorism (START). START is a U.S. Department of Homeland Security Center of Excellence, based at the University of Maryland, College Park.

The GTD dataset does not, however, distinguish between domestic and international terrorism attacks. It is, however, possible to separate them, allowing for a comparison of the determinants of domestic versus international terrorist events. An important recent contribution in this direction comes from Enders et al. (2011) who, similarly using the GTD dataset, propose a method to this end. We return to the differences between their approach and ours below.

In what follows, we explain how we perform this exercise through the reading of hundreds of terrorist group profiles, in an effort to identify the country of origin of the perpetrator group. The GTD was designed to gather a wide variety of etiological and situational variables proximate to each terrorist incident. The database records up to 128 separate attributes of each incident, including approximately 75 coded variables that can be used for statistical analysis. These variables can be grouped into the following categories:

1. Incident variables: provide information on the incident date, region, country, state/province, city, etc.

2. Perpetrator variables: provide information on the perpetrator group's name, claim of responsibility, etc.

3. Attack variables: provide information on the attack tactic, type of weapon (up to three weapon types), as well as specific types of cases such as kidnappings, hostage incidents, hijackings, etc.

4. Target variables: provide information on the nature, identity, corporation, and nationality (up to three nationalities) of the target.

5. Variables that capture the consequences of the attack: if the incident was considered a success, if and how claims of responsibility were made, amount of damage, total number of fatalities (persons, terrorists), and total number of injured (persons, terrorists).

6. The database also provides information on "doubting cases". 


\subsection{Operational definition of domestic terrorism}

In order to separate domestic from international terrorist events, we propose a precise definition of what we consider to be a domestic terrorist event. This can, in some cases, be controversial where the demarcation criterion is unclear.

Take, for instance, a simple definition whereby an event where the country of origin of the perpetrators is the same as the country where the attack occurs is considered domestic terrorism. Using this definition, an attack on a US Embassy will be considered a domestic event, and yet the standard classification of such an event will pool it with transnational events.

Domestic terrorism could also be defined as when the country of origin of the perpetrators is the same as the country of origin of the target group. Yet this definition also generates some gray areas. For instance, in the case of Colombia, the FARC regularly kidnapped foreign citizens. This would be considered domestic terrorism following the first definition, but international terrorism according to the second definition.

Enders et al. (2011) use a two-step procedure to identify domestic terrorism as residual events once international and uncertain events have been excluded from the dat $2^{19}$. We similarly employ this same first step to exclude the observations that do not correspond to a proper terrorist event. However, after this first step, we diverge from the algorithm proposed by Enders et al. (2011). Our main criterion to separately identify domestic and international terrorism relies on the country of origin of the perpetrator group, rather than the nationality of the victims 20 .

The GTD dataset provides the name of the perpetrator group. We examine each terrorist group profile so as to identify their origin, relying on different sources. One such source is the Terrorist Organization Profiles (TOPS). From 2004 through 2008, the Department of Justice and the Department of Homeland Security (DHS) provided support for the creation and ongoing maintenance of the Terrorism Knowledge Base, developed and sponsored by the Memorial Institute for the Prevention of Terrorism (MIPT), based in Oklahoma City. Through this project, MIPT partnered with Detica for the collection of information on terrorist groups and key leaders of terrorist groups. As explained above, MIPT also provides another dataset with information on terrorist events, but only domestic cases from 1998 on. We integrate TOPS information with the Global Terrorism Database. The TOPS also provide information on the motivation of the terrorist group: religious, 
separatist, nationalistic, anarchist, etc. In addition to these sources, we also use different encyclopedias and government sources, as well as newspapers and online resources to identify the country of origin of terrorist groups that appear in GTD, but not in TOPS.

When information on the origin of the perpetrators is not included in the TOPS, identification of the country of origin of the terrorists becomes more challenging. First of all, a terrorist group that appears in the GTD with a particular name may be called differently in other sources which provide biographies of the groups (e.g., TOPS, encyclopedias, government sources, newspapers, etc.). Secondly, some groups that operated in the past are now no longer active, making it more difficult to find information about them, particularly biographies, unless they were a very relevant movement. Third, many groups simply do not have biographies, such that we look to newspapers in Lexis-Nexus to identify their origin. Domestic groups also tend to be more challenging in that they have less visibility than transnational terrorist groups and therefore sometimes only appear in local newspapers.

\subsection{Geocodification of domestic terrorist attacks}

In order to be able to perform an analysis of terrorism at the subnational level, we needed to geolocate the coordinates of the terrorist events so as to determine the cell-country of the world grid where they occurred. We began with a dataset that reports 81,799 terrorist attacks. We aggregated this information by locations where these attacks took place. This process leaves 26,624 precise latitude and longitude locations with at least one terrorist attack.

Within countries, we found 499 cases where two or more towns had the same name. For example, in Mexico more than one town is named "Agua Blanca." Agua Blanca of Iturbide is located in central-eastern Mexico, but there is another Agua Blanca in Oaxaca State. In these cases, we were unable identify which city the dataset refers to.

In another 138 cases, we were unable to find the exact location of a place, and thus instead report the coordinates of the centroid of the province or state to which the place belongs. For example, Larbaais a town and commune in Tissemsilt Province,in northernAlgeria. As we were not able to find Larbaa's exact location, we report Tissemsilt Province's instead. For 28 cases we report the coordinates of a location near the place of the attack. For example, the town of Dand in Afghanistan is located just south of Kandahar City. 
Instead of Dand's latitude and longitude we report that of Kandahar City.

The primary sources of information used include:

- GeoHack (a tool used by Wikipedia to provide links to various mapping services when a user clicks on a link with geographical coordinates)

- Traveling Luck World Index (http://travelingluck.com/index.html)

- Getamap (http://es.getamap.net/)

- Geographic.org (http://geographic.org/)

- Others internet sources

Through use of these databases and the criteria referred to above, we georeferenced all terrorist events and classified them as domestic or international. We also constructed a variable identifying the classification that would result from the use of Enders et al. (2011) criteria to define domestic terrorism; that is residually from their definition of transnational terrorism.

\subsection{Data on earthquakes}

We use data from Significant Worldwide Earthquakes from the NGDC (NOAA's National Geophysical Data Center; http://www.ngdc.noaa.gov/).

The Significant Earthquake Database contains information on destructive earthquakes that meet at least one of the following criteria: at least moderate damage ( $\$ 1$ million or more), or at least 10 deaths, or a magnitude of 7.5 or greater, or earthquakes that generated tsunamis. The origin-times of the earthquakes are listed at different levels or precision across different databases, and some databases list origin-times for historical earthquakes in local time, rather than the more customary Coordinated Universal Time (UTC). Estimates of the hypocenters and magnitudes of earthquakes before about 1900 are often based on relatively scant evidence, and the compilers of catalogs sometimes differently interpreted such evidence. We only use earthquakes for which we have information on the magnitude, so as to preserve the exogeneity of the events.

\subsection{Seismic Hazard Maps}

One important concern is that the effect of an earthquake on the outcome variable could capture the effect of earthquake risk on development. It could 
be the case that in areas characterized by earthquake risk, people invested less due to the probability that an earthquake could destroy physical capital, etc. In order to address this concern we also control for earthquake hazard.

We use the information from the Global Seismic Hazard Map, produced by the Global Seismic Hazard Assessment Program (GSHAP). GSHAP was launched in 1992 by the International Lithosphere Program (ILP) with the support of the International Council of Scientific Unions (ICSU), and endorsed as a demonstration program in the framework of the United Nations International Decade for Natural Disaster Reduction (UN/IDNDR). The GSHAP project terminated in 199921.

The Global Seismic Hazard Assessment Program (GSHAP) was conducted with the goal of improving global standards in seismic hazard assessment. The GSHAP Global Seismic Hazard Map more specifically was compiled by joining regional maps produced for different GSHAP regions and test areas. It depicts the global seismic hazard as peak ground acceleration (pga) with a $10 \%$ chance of occurrence in 50 years, corresponding to a return period of 475 years.

Seismic hazard is defined as the probable level of ground shaking associated with the recurrence of earthquakes. This measure is exogenous. The GSHP distinguishes seismic hazard from seismic risk: "The assessment of seismic hazard is the first step in the evaluation of seismic risk, obtained by combining the seismic hazard with vulnerability factors (type, value and age of buildings and infrastructures, population density, land use, date, and time of the day). Frequent, large earthquakes in remote areas result in high seismic hazard but pose no risk; on the contrary, moderate earthquakes in densely populated areas entail small hazard but high risk" ${ }^{22}$. In this paper we use the seismic hazard which is exogenous to economic development. The Map 1 shows the different areas.

The hazard level is divided into 8 potential areas: the lowest hazard is white in color, depicting hazard values below 0.2 , the second lowest is a hazard level between 0.2 and 0.4 . The categories that follow have values: $0.4-0.8$, $0.8-1.6,1.6-2.4,2-4-3.2,3.2-4,4-4.8$, and $>4.8$ ).

Levels between 0 and 0.8 are considered low hazard, between 0.8 and 2.4 moderate hazard, between 2.4 and 4 high hazard, and those with values higher than 4 very high hazard. 


\subsection{Level of development}

To account for the influence of other factors, we include in the regression a variety of control variables. In particular, we include proxies for GDP. Information on GDP at the local level does not exist when using cell-country as units of observation. There are, for this reason, very few studies that use light density at night as a proxy for GDP at the cell level. As good data on income per capita are difficult to find at the grid/cell level, we follow Henderson et al. (2011) and use luminosity at night as a proxy for development. Satellite night light data are available from the National Oceanic and Atmospheric Administration. These data have also been used recently by Rohner et al. (2013) and Michalopoulos \& Papaioannou (2013).

All data was obtained from the National Geophysical Data Center, specifically the Earth Observation Group (EOG) reference to the DMSP-OLS Nighttime Lights Time Series version $4^{23}$. This first study is referenced at satellite F10 - year 1992. From the three available image types we use the stable light version, which ranges from values 1 to 63 . We also have information on nighttime light by square kilometer and the total nighttime light density by observation.

\subsection{A Geographical Description of the Relationship between Nightlight and Terrorism}

Before turning to the empirical analysis, in this section we show the precise location of terrorist events, distinguishing between domestic and international. We present the two definitions of domestic attacks considered above: our own definition and that of Enders et al. (2011). We have merged the latter information with the density of nightlight in 1992 calculated at the cell level. Map 2 to Map 9 compares the location of domestic terrorist events using the definition based on the origin of the perpetrator, and the approach in Enders et al. (2011). Since a relevant contribution of this paper is the construction of a new operational definition for domestic terrorism, it is interesting to represent graphically the distribution of all the events, considering their nature. The location of those events is included in the map the represents also luminosity at night. 


\section{Estimation and Main Results}

We now turn to the empirical results based on the precise location of terrorist events. Specifically, we exploit within-country variation, since we include a country fixed effect to capture common factors such as level of development, political institutions, and any historical aspects that might affect terrorism and patterns of local development. We then look for a correlation between terrorist events and the level of economic development in different regions of a country.

For this exercise, we use the cells whose construction we described in the section above. The core specification is the following:

$$
P_{j i}=\mu_{i}+\beta E A R T H Q_{j i}+\Sigma \gamma_{k} x_{k j i}+\epsilon_{j i}
$$

where $P_{j i}$ is the outcome measure in grid cell $j$ in country $i$ (mostly if there was at least one terrorist attack between 1994 and 2007), $\mu_{i}$ is a country fixed effect, $E A R T H Q_{j i}$ is a dummy variable for having an earthquake before 1992, and $x_{j i}$ are other grid cell controls indexed by $k$. Table 1 shows the main regression including the occurrence of an earthquake and the controls for its likelihood, as well as country fixed effects.

Table 1, Column 1, shows the simplest regression of terrorism on earthquakes without additional controls and including the whole sample. We report least square estimates and robust standard errors 24 . The occurrence of an earthquake in the past increases the likelihood of a domestic terrorist event during the period 1994-2007 by 19 percentage points (Column 2). When including country fixed effects the impact is reduced to 15 percentage points but it is still strongly statistically significant. Column 3 shows that the statistical significance of the estimator is unchanged if we use a robust standard error clustered at the country level despite the large increase in the standard error. Columns 4 to 8 restrict the sample to the cells that are populated. The size of the estimated parameter of the effect of the occurrence of an earthquake is unchanged. Columns 6 to 8 include proxies for the likelihood of a seismic event (global seismic hazard index or a dummy for areas with high seismic hazard) and confirm the results of the previous columns. Average seismic risk is not statistically significant although, when the indicator is operationalized by dummies representing different levels of seismic hazard, then the medium to high intervals become statistically significant.

Table 2 runs the basic specification of Table 1 including some additional controls. Column 1 includes controls for several geographical variables (distance to the coastline and ruggedness index) and climate (average temperature and 
average precipitation). The regressions also include in all the specifications the country fixed effect and the seismic hazard, so as to control for the a priori likelihood of a seismic event. Standard errors are always clustered at the country level. The estimate parameter for the occurrence of an earthquake is very similar to that reported in Table 1. Column 2 also includes population density as several papers have found this variable to be relevant to explaining conflict. In this case, the probability of a terrorist event decreases to 12 percentage points but is statistically significant. Column 3 includes the number of ethnic groups without generating any significant change in the size of the parameter of interest. Column 4 adds as a control the percentage of fertile soil while Column 5 includes the presence of borders with other countries and other geographical variables (distance to the closest river and distance to the closest lake).

Table 3 shows the robustness of the results to using alternative definitions and indicators for domestic terrorism. The controls include the largest set of them, which appear in the last column of Table 2. Column 1 uses the definition of domestic terrorism in Enders et al. (2011). The results are basically unaffected since the occurrence of an earthquake has a positive and significant effect on the likelihood of domestic terrorism. The size of the effect is similar to the estimates in Table 2. Columns 2 and 3 consider the number of terrorist acts in each cell using, respectively, our own definition and that of Enders et al. (2011). The results of the estimations of the specification with the two different definitions of terrorist events are very similar. The last two columns of Table 3 include the regressions on the number of events calculated using the ACLED and PRIO datasets. In the first case, the results are similar to those previously presented. When using the number of events in PRIO there is not a statistically significant effect.

Table 4 analyzes the impact of cities and urban agglomerations on the effect of the occurrence of earthquakes on terrorist events. As expected, urban concentrations attract more terrorist attacks. National capitals, provincial capitals, and, in general, urban agglomerations, have a higher likelihood of the occurrence of terrorist events than the other areas. However, the effect of the occurrence of earthquakes continues to have a positive and significant effect on the likelihood of domestic terrorist events even when we control for urban agglomerations or restrict the sample to the observations outside of urban agglomerations. That said, when controlling for urban agglomerations, the increase in the probability of a terrorist event in areas where there was an earthquake occurrence is reduced. Column 1 shows that controlling for the national capital reduces the probability to 10 percentage points higher in areas with the occurrence of an earthquake with respect to the other ar- 
eas. Including the capital of the province as well reduces the impact to 9 percentage points (Column 2). The effect is further reduced by the inclusion of a control for urban agglomerations. The estimates indicate a 7 percentage point higher probability of a terrorist event in areas with the occurrence of an earthquake (Column 3). Column 4 shows that the results are mostly identical if we drop all urban centers from the sample instead of controlling for urban agglomerations. Columns 5 and 6 present an alternative approach to the same issue. They exclude the richest areas (10\% and 20\% respectively). The findings are consistent with the previous results: the increase in the probability is reduced the richer the areas excluded from the sample. The same results are found if we exclude the most densely populated areas (Columns 7 and 8). In this case the estimated parameter is also reduced, as when dropping all the urban centers, but as in the previous columns it is still positive and statistically significant.

\section{The Relationship between Local Develop- ment and Terrorist Events}

The relationship between development and terrorism has long been a matter of debate. In the first section of this paper, we discussed the recent literature on this issue. We have, up until this section, avoided the use of any proxy for development as a control variable as it is likely to be endogenous. In what follows we analyze the suitability of the occurrence of an earthquake as an instrumental variable for income. The results of the previous tables could consequently be interpreted as reduce form estimations. Table 5 compiles the basic results including a proxy of the level of local development.

Panel A of Table 5 refers to the whole sample of populated cells. It shows that, in a reduced form specification, the level of development, measured using luminosity at night, has a positive but small effect on the likelihood of terrorist events, while the occurrence of an earthquake continues to have a positive and significant effect as observed in the previous tables. The second column presents the first stage where we can see that the occurrence of an earthquake in the past has a positive effect on nightlight even though the a priori seismic hazard index has a negative estimate. This is in line with the literature on the creative destruction of cities. Catastrophes, such as earthquakes, are often cited by historians as opportunities for improving urban development. Hornbeck \& Keniston (2017) argue that "economic growth and technological change require that cities be reconstructed to sup- 
port future urban growth." Since actual earthquakes are random events we can use this variable as an instrument to analyze the much debated question of the effect of development on terrorism. The third column presents the instrumental variables estimator, showing that the level of development has a positive estimate, much higher than without instrumenting local development, on the occurrence of domestic terrorist events. An increase of $10 \%$ in the level of development increases the probability of a terrorist event by 2 percentage points conditional on the rest of the control variables. This result is consistent with the so-called target effect: terrorists seeking to maximize the impact of their actions have historically targeted cities and densely populated areas.

Panel B of Table 5 shows that the results of the instrumental variable strategy for the whole world are robust to using only the sample of cells for African countries. Column 1 presents the reduced form with all the controls. It shows that the estimate of the occurrence of an earthquake increases the probability of a terrorist event in a percentage similar to the whole world. Column 2 shows the first stage and, therefore, the relationship between development and the occurrence of seismic events. There is a strong and positive correlation of the occurrence of earthquakes on the level of development. The final Column 3 shows that instrumenting development using earthquakes produces an estimate for development that is much larger than that obtained without using the instrument as in the case of Panel A of Table 5. In the case of African countries, and conditional on the other control variables, an increase of $10 \%$ in the development indicator increases the likelihood of a terrorist event by 2.5 percentage points.

Using the sample of cells of African countries, it is also possible to investigate alternative channels to income of the effect of earthquakes on terrorism. For instance, terrorist events can generate low trust on governments unable to deal appropriately with the consequences of the earthquake. The Afrobarometer is a household level survey, which explores a host of attitudinal questions among the citizens of African countries. Here we use data collected in 2008 (the third round) from surveys conducted with a total of 25,397 respondents in 18 countries: Benin, Botswana, Cape Verde, Ghana, Kenya, Lesotho, Madagascar, Malawi, Mali, Mozambique, Namibia, Nigeria, Senegal, South Africa, Tanzania, Uganda, Zambia, and Zimbabwe. Each survey strives to be representative of the population and interviews are conducted in local languages. Table 6 looks at the issue of trust (i.e., inter-group, neighbors, relatives, and intra-group) where the survey asks to what extent the respondent trusts others. Answers are given on a four-point scale where zero is "not at all," one is "just a little," two is "somewhat," and three is "a lot." 
Columns 3 and 4 examine another variable from the Afrobarometer which reports self-ascribed ethnic identity. The specification includes all the grid-cell variables used in the previous tables plus age, gender, and dummies for urban location, education, occupation, and religion. Table 6 shows that only trust in neighbors seems to be affected by the occurrence of a previous earthquake. Trust in parliament, the president or prime minister, local politicians, etc. seems unaffected by the previous occurrence of an earthquake.

\section{Conclusions}

The literature on the effect of shocks on civil conflicts has grown rapidly over the last decade. A strand of this research line emphasizes the effect of climate shocks on violence and political instability. Some of these papers argue that the transmission mechanism of these shocks is channeled through climate-induced changes in income, although this remains a matter of debate. Most of the research on shocks and violence focuses on climate shocks (e.g., abnormal temperatures, extreme rainfall episodes, etc.) although there are also examples relating natural disasters such as earthquakes to civil conflict (Brancati, 2007) and political transitions.

In this paper we present evidence of the relationship between earthquakes and terrorism. We find empirical support for this connection even many years after the occurrence of the earthquake. Brancati (2007) similarly shows that high intensity earthquakes produce a large increase in the probability of civil wars. Earthquakes may in fact produce an inadequate response from the government and generate, or exacerbate, previous grievances perceived by the population of the affected area. An earthquake can also increase the salience of these grievances should government reaction in helping the poor, or a particular ethnic/religious/social group, be perceived as slower/weaker than that provided to other groups. As destruction of infrastructures would be limited, the state will keep its coercive capacity, reducing the chances of a full-fledged conflict but leaving open the possibility of low intensity rebellious acts as terrorism. If the recovery of economic activity is fast, then the opportunity cost of rebellion will quickly decrease. In this case, economic conditions may recover but resentment towards authorities will remain high long after the occurrence of the earthquake.

We make two contributions to the literature on terrorism. First, we construct a novel and comprehensive dataset that provides information on 80,000 terrorist events from 1970 to 2007, and separates them into domestic terrorist 
acts and transnational events. Second, we conduct a geographically detailed empirical analysis at the subnational level using all the countries in the world. The units of observation are grid-cells of $120 \mathrm{~km}$ x $120 \mathrm{~km}$. Since terrorist events are usually concentrated in very specific parts of each country, we believe that it is important to study the determinants of domestic terrorism at the subnational level.

The empirical results show that the likelihood of terrorist events increases with the previous occurrence of an earthquake. Using the occurrence of an earthquake as an instrumental variable, we find that the impact of income on the likelihood of terrorist events is much higher than its effect when the likely endogenous nature of development is not considered. 


\section{References}

Abadie, A. (2006). Poverty, political freedom, and the roots of terrorism. American Economic Review, 96(2), 50-56.

Abadie, A., \& Gardeazabal, J. (2008). Terrorism and the world economy. European Economic Review, 52(1), 1-27.

Alesina, A., Giuliano, P., \& Nunn, N. (2013). On the origins of gender roles: Women and the plough. The Quarterly Journal of Economics, 128(2), 469-530.

Angrist, J. D., \& Kugler, A. D. (2008). Rural windfall or a new resource curse? coca, income, and civil conflict in colombia. The Review of Economics and Statistics, 90(2), 191-215.

Aragón, F. M., \& Rud, J. P. (2013). Natural resources and local communities: evidence from a peruvian gold mine. American Economic Journal: Economic Policy, 5(2), 1-25.

Bazzi, S., \& Blattman, C. (2014). Economic shocks and conflict: Evidence from commodity prices. American Economic Journal: Macroeconomics, $6(4), 1-38$.

Belloc, M., Drago, F., \& Galbiati, R. (2016). Earthquakes, religion, and transition to self-government in italian cities. The Quarterly Journal of Economics, 131(4), 1875-1926.

Benjamin, F., Melissa, D., Benjamin, O., et al. (2013). What do we learn from the weather? the new climate-economy literature. NBER Working Papers.

Berman, N., \& Couttenier, M. (2015). External shocks, internal shots: the geography of civil conflicts. Review of Economics and Statistics, 97(4), 758-776.

Berman, N., Couttenier, M., Rohner, D., \& Thoenig, M. (2017). This mine is mine! how minerals fuel conflicts in africa. American Economic Review, $107(6), 1564-1610$.

Berrebi, C., \& Ostwald, J. (2011). Earthquakes, hurricanes, and terrorism: do natural disasters incite terror? Public Choice, $149(3-4), 383$.

Brancati, D. (2007). Political aftershocks: The impact of earthquakes on intrastate conflict. Journal of Conflict Resolution, 51(5), 715-743. 
Chassang, S., \& Padro-i Miquel, G. (2009). Economic shocks and civil war. Quarterly Journal of Political Science, 4(3), 211-228.

Choi, S.-W., \& Piazza, J. A. (2016). Ethnic groups, political exclusion and domestic terrorism. Defence and Peace Economics, 27(1), 37-63.

Ciccone, A. (2008). Economic shocks and civil conflict: A comment.

Dal Bó, E., \& Dal Bó, P. (2011). Workers, warriors, and criminals: social conflict in general equilibrium. Journal of the European Economic Association, 9(4), 646-677.

Dell, M. (2010). The persistent effects of peru's mining mita. Econometrica, $78(6), 1863-1903$.

Dell, M. (2012). Path dependence in development: Evidence from the mexican revolution. Harvard University, mimeograph.

Dube, O., \& Vargas, J. F. (2013). Commodity price shocks and civil conflict: Evidence from colombia. The Review of Economic Studies, 80(4), 13841421.

Enders, W., Hoover, G. A., \& Sandler, T. (2016). The changing nonlinear relationship between income and terrorism. Journal of Conflict Resolution, $60(2), 195-225$.

Enders, W., Parise, G. F., \& Sandler, T. (1992). A time-series analysis of transnational terrorism: Trends and cycles. Defence and Peace Economics, 3(4), 305-320.

Enders, W., \& Sandler, T. (1993). The effectiveness of antiterrorism policies: A vector-autoregression-intervention analysis. American Political Science Review, 87(4), 829-844.

Enders, W., \& Sandler, T. (1999). Transnational terrorism in the post-cold war era. International Studies Quarterly, 43(1), 145-167.

Enders, W., \& Sandler, T. (2000). Is transnational terrorism becoming more threatening? a time-series investigation. Journal of Conflict Resolution, $44(3), 307-332$.

Enders, W., Sandler, T., \& Gaibulloev, K. (2011). Domestic versus transnational terrorism: Data, decomposition, and dynamics. Journal of Peace Research, 48(3), 319-337.

Fearon, J. D., \& Laitin, D. D. (2003). Ethnicity, insurgency, and civil war. American political science review, 97(1), 75-90. 
Findley, M. G., Braithwaite, A., Young, J. K., Marineau, J. F., \& Pascoe, H. (2015). The local geography of transnational terrorism. In International studies association annual meeting, new orleans, louisiana.

Gaibulloev, K. (2014). Terrorist group location decision: an empirical investigation. Oxford Economic Papers, 67(1), 21-41.

Habibur Rahman, M., Anbarci, N., Bhattacharya, P. S., \& Ulubaşoğlu, M. A. (2017). The shocking origins of political transitions: Evidence from earthquakes. Southern Economic Journal, 83(3), 796-823.

Harari, M., \& La Ferrara, E. (2013). Conflict, climate and cells: A disaggregated analysis.

Henderson, V., Storeygard, A., \& Weil, D. N. (2011). A bright idea for measuring economic growth. The American economic review, 101(3), 194199.

Hornbeck, R. (2012). The enduring impact of the american dust bowl: Shortand long-run adjustments to environmental catastrophe. The American Economic Review, 102(4), 1477-1507.

Hornbeck, R., \& Keniston, D. (2017). Creative destruction: Barriers to urban growth and the great boston fire of 1872. American Economic Review, $107(6), 1365-98$.

Hornbeck, R., \& Naidu, S. (2014). When the levee breaks: black migration and economic development in the american south. The American Economic Review, 104(3), 963-990.

Hsiang, S. M., Burke, M., \& Miguel, E. (2013). Quantifying the influence of climate on human conflict. Science, 341(6151), 1235367.

Im, E. I., Cauley, J., \& Sandler, T. (1987). Cycles and substitutions in terrorist activities: A spectral approach. Kyklos, 40(2), 238-255.

Jia, R. (2014). Weather shocks, sweet potatoes and peasant revolts in historical china. The Economic Journal, 124(575), 92-118.

Keefer, P., \& Loayza, N. (2008). Terrorism, economic development, and political openness. Cambridge University Press.

Kelman, I. (2011). Disaster diplomacy: how disasters affect peace and conflict. Routledge. 
Krueger, A. B., \& Laitin, D. D. (2008). Kto kogo?: A cross-country study of the origins and targets of terrorism. Terrorism, economic development, and political openness, 148-173.

Krueger, A. B., \& Maleckova, J. (2002). Education, poverty, political violence and terrorism: Is there a causal connection? (Tech. Rep.). National Bureau of Economic Research.

Ladner, P., \& Persson, T. (2009). The origins of state capacity: Property rights, taxation, and politics. The American Economic Review, 99(4), $1218-1244$.

Loayza, N. V., Olaberria, E., Rigolini, J., \& Christiaensen, L. (2012). Natural disasters and growth: going beyond the averages. World Development, 40(7), 1317-1336.

Maystadt, J.-F., Calderone, M., \& You, L. (2014). Local warming and violent conflict in north and south sudan. Journal of Economic Geography, 15(3), 649-671.

Michalopoulos, S., \& Papaioannou, E. (2013). Pre-colonial ethnic institutions and contemporary african development. Econometrica, 81(1), 113-152.

Mickolus, E. F. (1980). Transnational terrorism: A chronology of events, 1968-1979. Aldwych Press London.

Mickolus, E. F. (1982). International terrorism: Attributes of terrorist events, 1968-197ry (iterate 2). Inter-university Consortium for Political and Social Research.

Mickolus, E. F., Sandler, T., Murdock, J. M., \& Fleming, P. (1989). International terrorism: Attributes of terrorist events 1978-1987 (iterate 3). Vinyard Software, Inc., Ames, IA.

Nemeth, S. C., Mauslein, J. A., \& Stapley, C. (2014). The primacy of the local: Identifying terrorist hot spots using geographic information systems. The Journal of Politics, 76 (2), 304-317.

Piazza, J. A. (2006). Rooted in poverty?: Terrorism, poor economic development, and social cleavages 1. Terrorism and Political Violence, 18(1), $159-177$.

Piazza, J. A. (2011). Poverty, minority economic discrimination, and domestic terrorism. Journal of Peace Research, 48(3), 339-353. 
Python, A., Brandsch, J., \& Tskhay, A. (2017). Provoking local ethnic violence-a global study on ethnic polarization and terrorist targeting. Political Geography, 58, 77-89.

Rohner, D., Thoenig, M., \& Zilibotti, F. (2013). War signals: A theory of trade, trust, and conflict. Review of Economic Studies, 80 (3), 1114-1147.

Sambanis, N. (2008). Terrorism and civil war. Terrorism, economic development, and political openness, 174-206.

Sandler, T. (2014). The analytical study of terrorism: Taking stock. Journal of Peace Research, 51(2), 257-271.

Sandler, T., Tschirhart, J. T., \& Cauley, J. (1983). A theoretical analysis of transnational terrorism. American Political Science Review, 77(1), 36-54.

Savun, B., \& Phillips, B. J. (2009). Democracy, foreign policy, and terrorism. Journal of Conflict Resolution, 53(6), 878-904.

Vidal-Robert, J. (2011). An economic analysis of the spanish inquisition's motivations and consequences. Unpublished Manuscript. 
Table 1: Terrorism and Earthquakes

\begin{tabular}{|c|c|c|c|c|c|c|c|c|}
\hline \multicolumn{9}{|c|}{ Dependent Variable: Domestic Terrorist Events 1994-2007 (yes $=1$ ) } \\
\hline & $\begin{array}{l}\text { All Sample } \\
\text { (1) }\end{array}$ & $\begin{array}{l}\text { All Sample } \\
\text { (2) }\end{array}$ & $\begin{array}{c}\text { All Sample } \\
\text { (3) }\end{array}$ & $\begin{array}{c}\text { Only } \\
\text { Populated Areas } \\
(4)\end{array}$ & $\begin{array}{c}\text { Only } \\
\text { Populated Areas } \\
\text { (5) }\end{array}$ & $\begin{array}{c}\text { Only } \\
\text { Populated Areas } \\
(6)\end{array}$ & $\begin{array}{c}\text { Only } \\
\text { Populated Areas } \\
(7)\end{array}$ & $\begin{array}{c}\text { Only } \\
\text { Populated Areas } \\
\text { (8) }\end{array}$ \\
\hline Earthquake occurrence (yes=1) & $0.191^{* * *}$ & $0.155^{* * *}$ & $0.155^{* * *}$ & $0.155^{* * *}$ & $0.155^{* * *}$ & $0.150^{* * *}$ & $0.149^{* * *}$ & $0.154^{* * *}$ \\
\hline Global Seismic Hazard Index & & & & & & 0.005 & & \\
\hline High Seismic Hazard $($ yes $=1)$ & & & & & & & & 0.007 \\
\hline Seismic Hazard Dummies FE & No & No & No & No & No & No & Yes & No \\
\hline Country FE & No & Yes & Yes & Yes & Yes & Yes & Yes & Yes \\
\hline Observation & 25,825 & 25,825 & 25,825 & 21,516 & 21,516 & 21,516 & 21,516 & 21,516 \\
\hline R-squared & 0.046 & 0.204 & 0.204 & 0.198 & 0.198 & 0.198 & 0.200 & 0.198 \\
\hline
\end{tabular}

Note: In columns 1,2 and 4 we report robust standard error in brackets. In columns $3,5,6,7$ and 8 , robust standard error in brackets clustered at country level are reported in
brackets. $*$ Significant at $10 \%, * *$ significant at $5 \%$, and $* * *$ significant at $1 \%$ 
Table 2: Terrorism and Earthquake - Extra Analysis

\begin{tabular}{|c|c|c|c|c|c|}
\hline \multicolumn{6}{|c|}{ Dependent Variable: Domestic Terrorist Events 1994-2007 (yes=1) } \\
\hline & (1) & (2) & (3) & (4) & (5) \\
\hline Earthquake occurrence $($ yes $=1)$ & $\begin{array}{c}0.146^{* * *} \\
{[0.035]}\end{array}$ & $0.127^{* * *}$ & $0.122^{* * *}$ & $0.122^{* * *}$ & $0.116^{* * *}$ \\
\hline Global Seismic Hazard Index & & & 0.003 & & \\
\hline & {$[0.003]$} & {$[0.003]$} & {$[0.003]$} & {$[0.003]$} & [0.003] \\
\hline Log Population Density & & $0.016^{* * * *}$ & $0.016^{* * * *}$ & $0.014^{* * * *}$ & $0.014^{* * * *}$ \\
\hline Number of Ethnic Groups & & {$[0.005]$} & $0.017^{* * * *}$ & $0.017^{* * *}$ & $0.019^{* * *}$ \\
\hline Share Mining & & & {$[0.005]$} & {$[0.005]$} & {$[0.006]$} \\
\hline Silare tvititity & & & & {$[0.091]$} & {$[0.087]$} \\
\hline \% Fertile Soil & & & & $\begin{array}{l}0.000^{*} \\
{[0.000]}\end{array}$ & $\begin{array}{l}0.000^{*} \\
{[0.000]}\end{array}$ \\
\hline Border $($ yes $=1)$ & & & & & $\begin{array}{l}-0.030^{* * *} \\
{[0.007\rceil}\end{array}$ \\
\hline Geographic Variables & Yes & Yes & Yes & Yes & Yes \\
\hline Climate Variables & Yes & Yes & Yes & Yes & Yes \\
\hline Country FE & Yes & Yes & Yes & Yes & Yes \\
\hline Other Geographic & No & No & No & No & Yes \\
\hline $\begin{array}{l}\text { Observations } \\
\text { R-squared }\end{array}$ & $\begin{array}{c}21,516 \\
0.205\end{array}$ & $\begin{array}{c}21,516 \\
0.222\end{array}$ & $\begin{array}{c}21,516 \\
0,227\end{array}$ & $\begin{array}{c}21,516 \\
0,228\end{array}$ & $\begin{array}{c}21,516 \\
0,232\end{array}$ \\
\hline
\end{tabular}

N Notes - Robust standard error clustered at country level are reported in brackets. ${ }^{*}$ Significant at $10 \%,{ }^{* *}$ significant at $5 \%$, and ${ }^{* * *}$ significant at $1 \%$. Geographic Variables include distance to coastline $(\mathrm{km})$ and Distance to Lake $(\mathrm{km})$. 
Table 3: Earthquakes and alternative measures

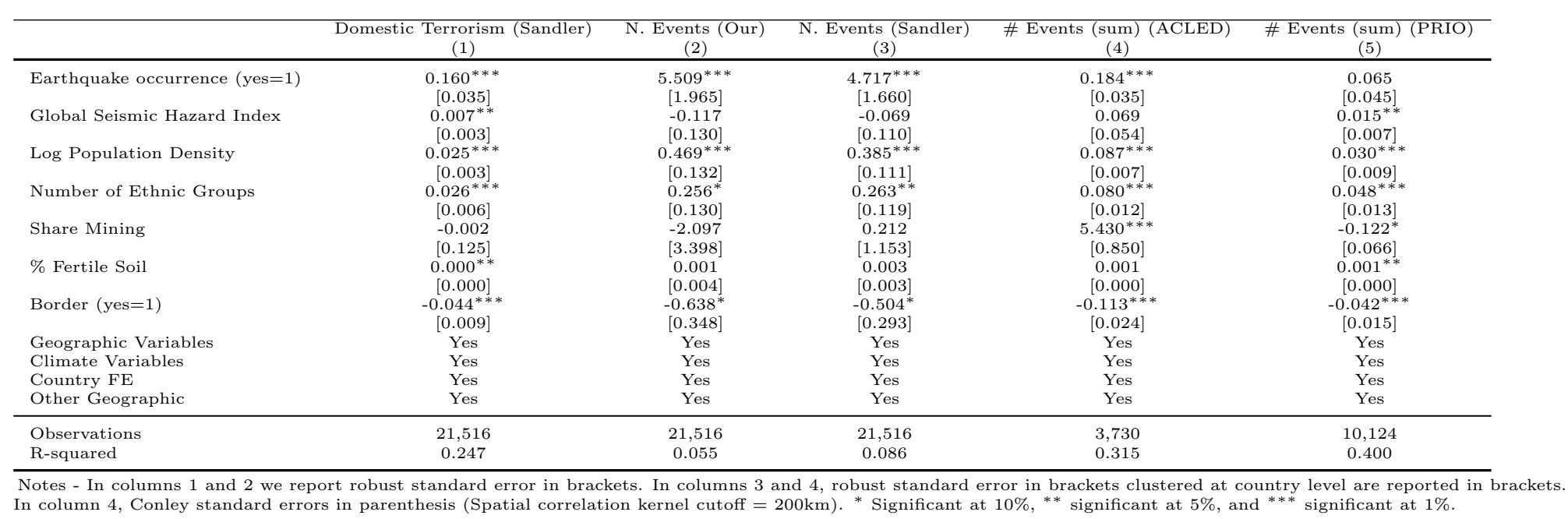


Table 4: Earthquakes and Terrorism: the role of agglomeration effect

\begin{tabular}{|c|c|c|c|c|c|c|c|c|}
\hline & (1) & (2) & (3) & $\begin{array}{l}\text { Drop all-urban } \\
\text { center } \\
(4)\end{array}$ & $\begin{array}{c}\text { Drop } 10 \% \\
\text { richest } \\
(5)\end{array}$ & $\begin{array}{c}\begin{array}{c}\text { Drop 20\% } \\
\text { richest } \\
(6)\end{array} \\
\end{array}$ & $\begin{array}{c}\text { Drop 10\% } \\
\text { most densely } \\
(7)\end{array}$ & $\begin{array}{c}\text { Drop 20\% } \\
\text { most densely } \\
(8)\end{array}$ \\
\hline $\begin{array}{l}\text { Earthquake occurrence (yes=1) } \\
\text { Global Seismic Hazard Index } \\
\text { Nat. Capital (yes=1) } \\
\text { Prov. Capital (yes=1) } \\
\text { Urb. Agglom (yes=1) }\end{array}$ & $\begin{array}{c}0.106^{* * *} \\
{[0.031]} \\
0.004 \\
{[0.003]} \\
0.304^{* * *} \\
{[0.034]}\end{array}$ & $\begin{array}{c}0.092^{* * *} \\
{[0.030]} \\
0.004 \\
{[0.003]} \\
0.236^{* * *} \\
{[0.033]} \\
0.119^{* * *} \\
{[0.017]}\end{array}$ & $\begin{array}{c}0.067^{* *} \\
{[0.028]} \\
0.006^{* *} \\
{[0.003]} \\
0.204^{* * *} \\
{[0.036]} \\
0.088^{* * *} \\
{[0.019]} \\
0.127^{* * *} \\
{[0.036]}\end{array}$ & $\begin{array}{c}0.068^{* * *} \\
{[0.024]} \\
0.002 \\
{[0.002]}\end{array}$ & $\begin{array}{c}0.116^{* * *} \\
{[0.032]} \\
0.005 \\
{[0.003]}\end{array}$ & $\begin{array}{c}0.123 * * * \\
{[0.037]} \\
0.005 \\
{[0.004]}\end{array}$ & $\begin{array}{c}0.078^{* * *} \\
{[0.023]} \\
0.002 \\
{[0.002]}\end{array}$ & $\begin{array}{c}0.040^{* * * *} \\
{[0.013]} \\
-0.001 \\
{[0.001]}\end{array}$ \\
\hline Controls from C6 Table 2 & Yes & Yes & Yes & Yes & Yes & Yes & Yes & Yes \\
\hline $\begin{array}{l}\text { Observations } \\
\text { R-squared }\end{array}$ & $\begin{array}{c}21,516 \\
0.249\end{array}$ & $\begin{array}{c}21,516 \\
0.267\end{array}$ & $\begin{array}{l}21,516 \\
0.287\end{array}$ & $\begin{array}{c}18,176 \\
0.140\end{array}$ & $\begin{array}{c}19,151 \\
0.234\end{array}$ & $\begin{array}{c}14,845 \\
0.264\end{array}$ & $\begin{array}{c}19,150 \\
0.184\end{array}$ & $\begin{array}{c}16,998 \\
0.143\end{array}$ \\
\hline
\end{tabular}

Notes - Robust standard error clustered at country level are reported in brackets. ${ }^{*}$ Significant at $10 \%,{ }^{* *}$ significant at $5 \%$, and ${ }^{* * *}$ significant at $1 \%$. Country fixed effects are

included. Controls from C6 Table 2 include: distance to coastline, Ruggedness Index, Average temperature from 1961-1980, average precipitation from 1961-1980, , Log Population
1990 , Area, Share Mining \% Fertile Soil, Distance to River, Distance to Le and Border (yes=1). 
Table 5: Earthquakes and Domestic Terrorism and regional development

\begin{tabular}{|c|c|c|c|c|c|c|}
\hline & \multicolumn{3}{|c|}{ Panel A } & \multicolumn{3}{|c|}{ Panel B } \\
\hline & $\begin{array}{l}\text { Terrorism } \\
\text { OLS }\end{array}$ & $\begin{array}{c}\text { Log. Nightlight } 1992 \\
\text { OLS }\end{array}$ & $\begin{array}{c}\text { Terrorism } \\
\text { IV }\end{array}$ & $\begin{array}{l}\text { Terrorism } \\
\text { OLS }\end{array}$ & $\begin{array}{l}\text { Log. Nightlight } 1992 \\
\text { OLS }\end{array}$ & $\begin{array}{c}\text { Terrorism } \\
\text { IV }\end{array}$ \\
\hline Earthquake occurrence (yes=1) & $0.115^{* * *}$ & $0.531^{* * *}$ & & $0.184^{* * *}$ & $1.224^{* * *}$ & \\
\hline Log night light 1992 & $0.002^{*}$ & & $0.219^{* *}$ & $0.005^{* * * *}$ & & $0.150^{* * *}$ \\
\hline Clobal Seismic Hazard Jnder & {$[0.001]$} & $0187^{* *}$ & {$[0.096]$} & {$[0.002]$} & & {$[0.059]$} \\
\hline Global Seismic Hazard Index & {$[0.003]$} & $\left.\begin{array}{l}-0.101 \\
{[0.073]}\end{array}\right]$ & {$[0.018]$} & {$[0.023]$} & - -0.202 & {$[0.053]$} \\
\hline Controls from Table 2 C5 & Yes & Yes & Yes & Yes & Yes & Yes \\
\hline $\begin{array}{l}\text { Observations } \\
\text { R-squared }\end{array}$ & $\begin{array}{c}21,516 \\
0.233\end{array}$ & $\begin{array}{c}21,516 \\
0.429\end{array}$ & 21,516 & $\begin{array}{l}3,715 \\
0.237\end{array}$ & $\begin{array}{l}3,715 \\
0.396\end{array}$ & 3,715 \\
\hline
\end{tabular}

Notes - In columns 1 and 2 we report robust standard error in brackets. In columns 3 and 4 , robust standard error in brackets clustered at country level are repote
column 4 , Conley standard errors in parenthesis (Spatial correlation kernel cutoff $=200 \mathrm{~km}$ ) $*$ Significant at $10 \%, * *$ significant at $5 \%$, and $* * *$ significant at $1 \%$. 
Table 6: Terrorism and Trust - Afrobarometer

\begin{tabular}{|c|c|c|c|c|c|c|c|c|}
\hline & $\begin{array}{c}\text { Trust your } \\
\text { relatives } \\
(1) \\
\end{array}$ & $\begin{array}{c}\text { Trust your } \\
\text { neighbors } \\
(2) \\
\end{array}$ & $\begin{array}{c}\text { Trust people } \\
\text { from your own } \\
\text { ethnic group } \\
\text { (3) } \\
\end{array}$ & $\begin{array}{l}\text { Trust people } \\
\text { from other } \\
\text { ethnic group } \\
\text { (4) } \\
\end{array}$ & $\begin{array}{c}\text { Trust the } \\
\text { President or } \\
\text { Prime Minister } \\
\text { (5) } \\
\end{array}$ & $\begin{array}{c}\text { Trust the } \\
\text { Parliament or } \\
\text { National Assembly } \\
\text { (6) }\end{array}$ & $\begin{array}{c}\text { Trust your } \\
\text { Elected Local } \\
\text { Government Council } \\
(7) \\
\end{array}$ & $\begin{array}{c}\text { Religiousness } \\
\text { (8) } \\
\end{array}$ \\
\hline $\begin{array}{l}\text { Earthquake occurrence (yes=1) } \\
\text { Global Seismic Hazard Index } \\
\text { Controls from C6 Table } 2\end{array}$ & $\begin{array}{c}-0.073 \\
{[0.081]} \\
-0.037 \\
{[0.129]} \\
\text { Yes }\end{array}$ & $\begin{array}{c}-0.262^{* * *} \\
{[0.086]} \\
-0.034 \\
{[0.163]} \\
\text { Yes }\end{array}$ & $\begin{array}{c}-0.082 \\
{[0.081]} \\
0.074 \\
{[0.183]} \\
\text { Yes }\end{array}$ & $\begin{array}{c}0.087 \\
{[0.088]} \\
0.050 \\
{[0.114]} \\
\text { Yes }\end{array}$ & $\begin{array}{c}0.179 \\
{[0.143]} \\
-0.005 \\
{[0.161]} \\
\text { Yes }\end{array}$ & $\begin{array}{c}0.011 \\
{[0.113]} \\
-0.097 \\
{[0.097]} \\
\text { Yes }\end{array}$ & $\begin{array}{c}0.021 \\
{[0.071]} \\
0.005 \\
{[0.165]} \\
\text { Yes }\end{array}$ & $\begin{array}{c}-0.068 \\
{[0.115]} \\
0.003 \\
{[0.139]} \\
\text { Yes }\end{array}$ \\
\hline $\begin{array}{l}\text { Observations } \\
\text { R-squared }\end{array}$ & $\begin{array}{c}620 \\
0.335\end{array}$ & $\begin{array}{c}620 \\
0.354\end{array}$ & $\begin{array}{c}620 \\
0.365\end{array}$ & $\begin{array}{c}620 \\
0.317\end{array}$ & $\begin{array}{c}647 \\
0.554\end{array}$ & $\begin{array}{c}647 \\
0.519\end{array}$ & $\begin{array}{c}647 \\
0.517\end{array}$ & $\begin{array}{c}647 \\
0.368\end{array}$ \\
\hline
\end{tabular}

Notes - Robust standard error clustered at country level are reported in brackets. ${ }^{*}$ Significant at $10 \%,{ }^{* *}$ significant at $5 \%$, and ${ }^{* * *}$ significant at $1 \%$. Geographic Variables include: distance to coastline and Ruggedness Index. Climate Controls: Average temperature from 1961-1980 and average precipitation from 1961-1980. Other Geographic= \% Fertile Soil,
Distance to River $(\mathrm{km})$, Distance to Lake $(\mathrm{km})$ and Border (yes=1). 


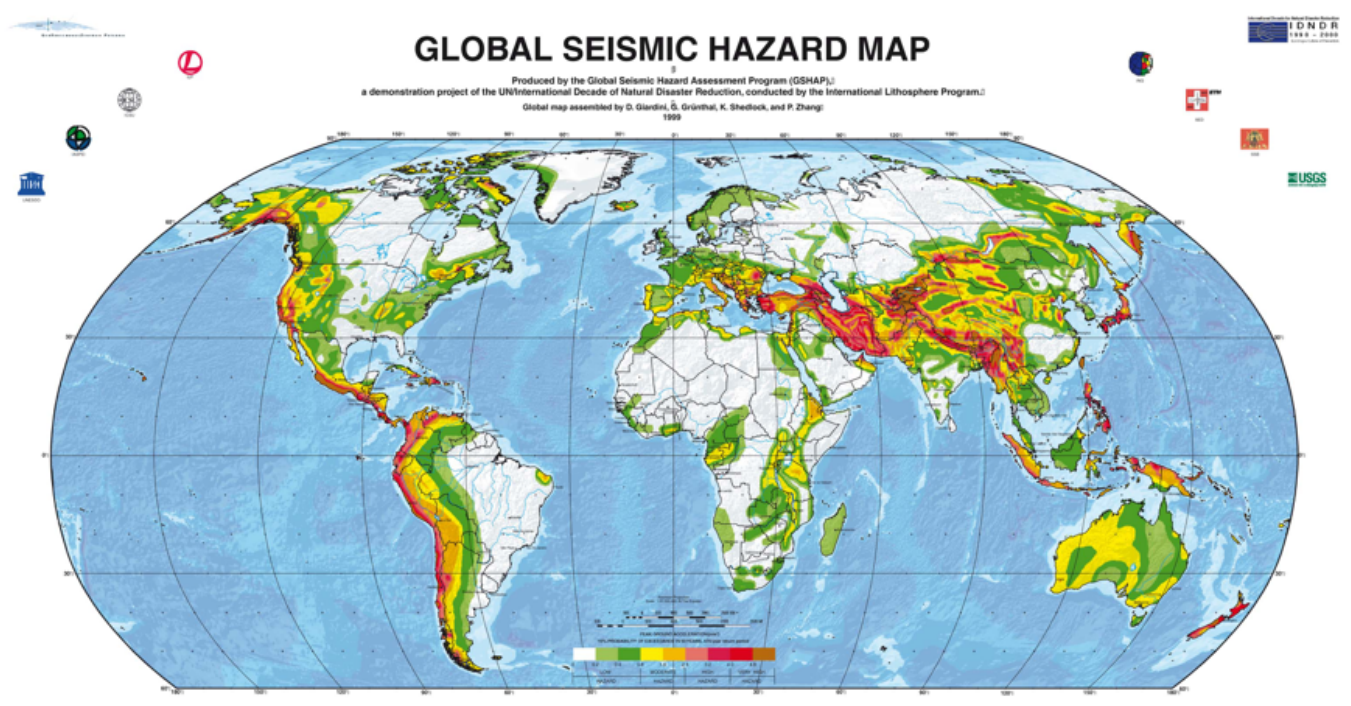

Figure 1: Global seismic hazard map. 


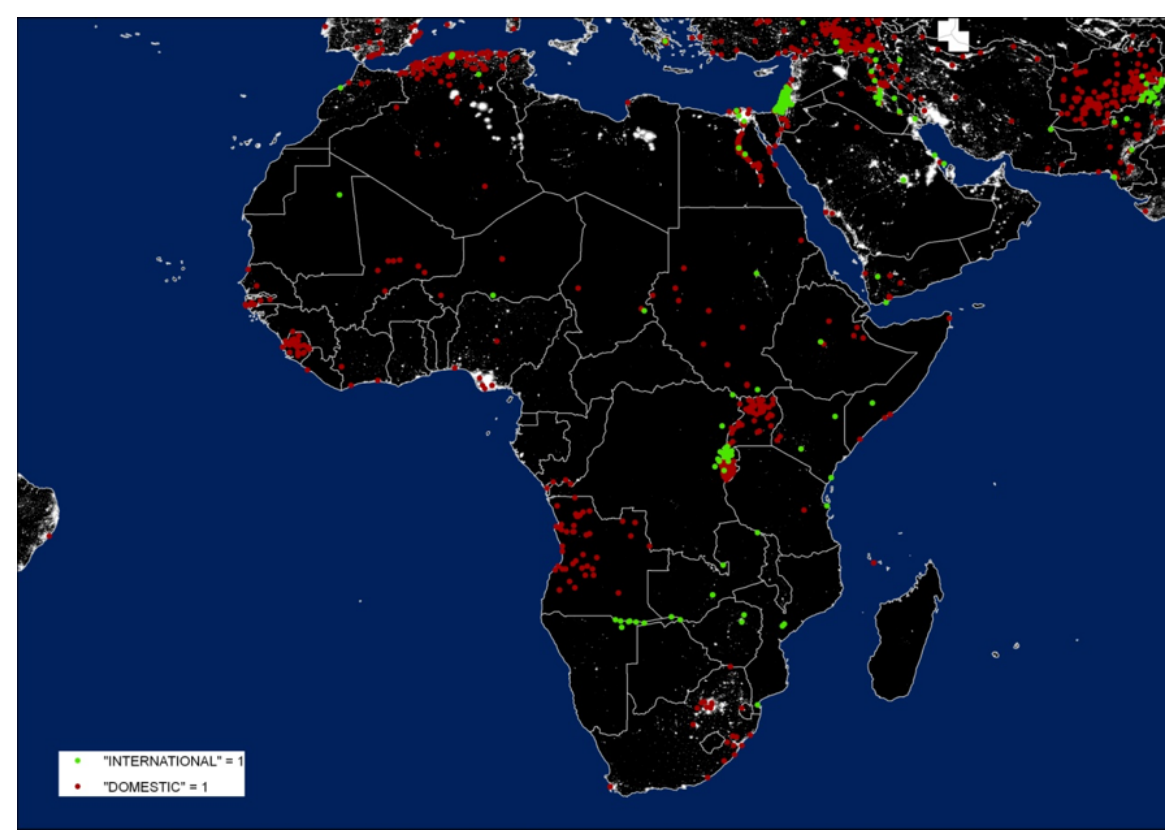

Figure 2: Domestic terrorism (by origin of perpetrators) and nightlight: Africa.

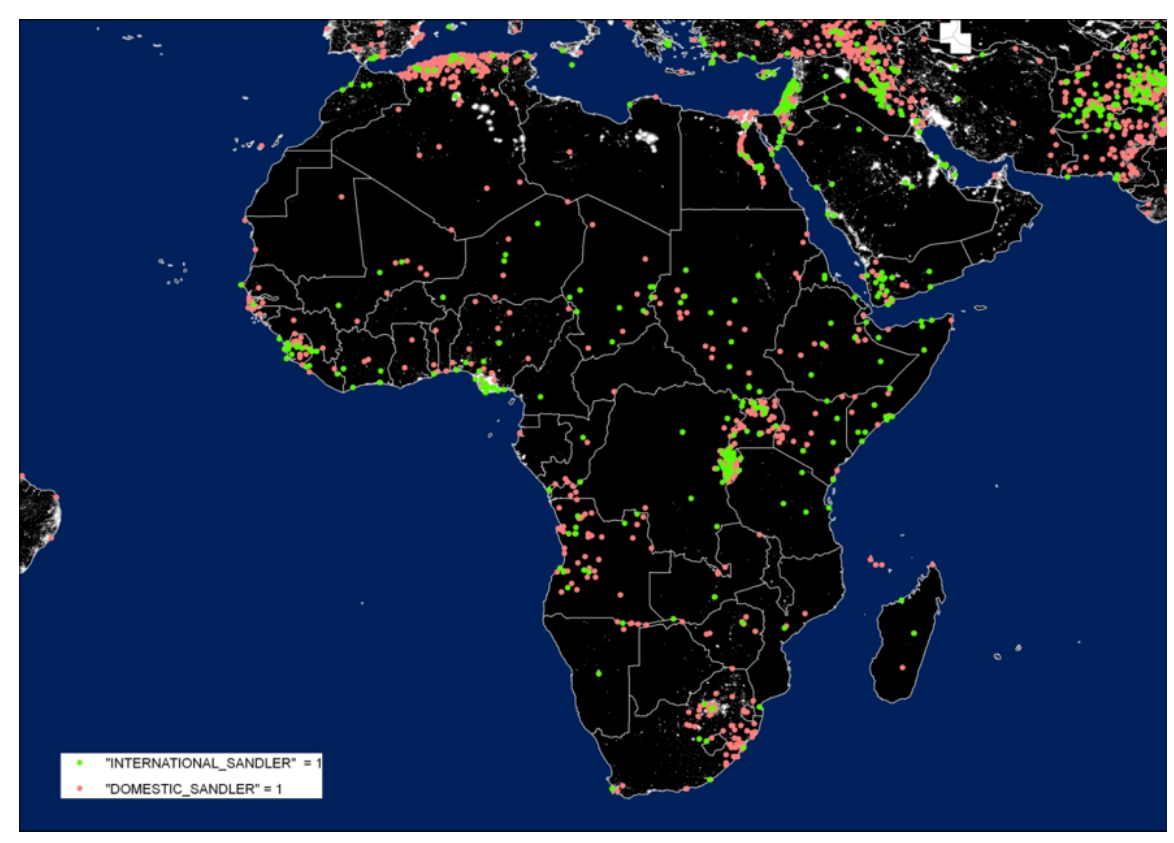

Figure 3: Enders et al.'s (2011) definition of domestic terrorism and nightlight: Africa. 


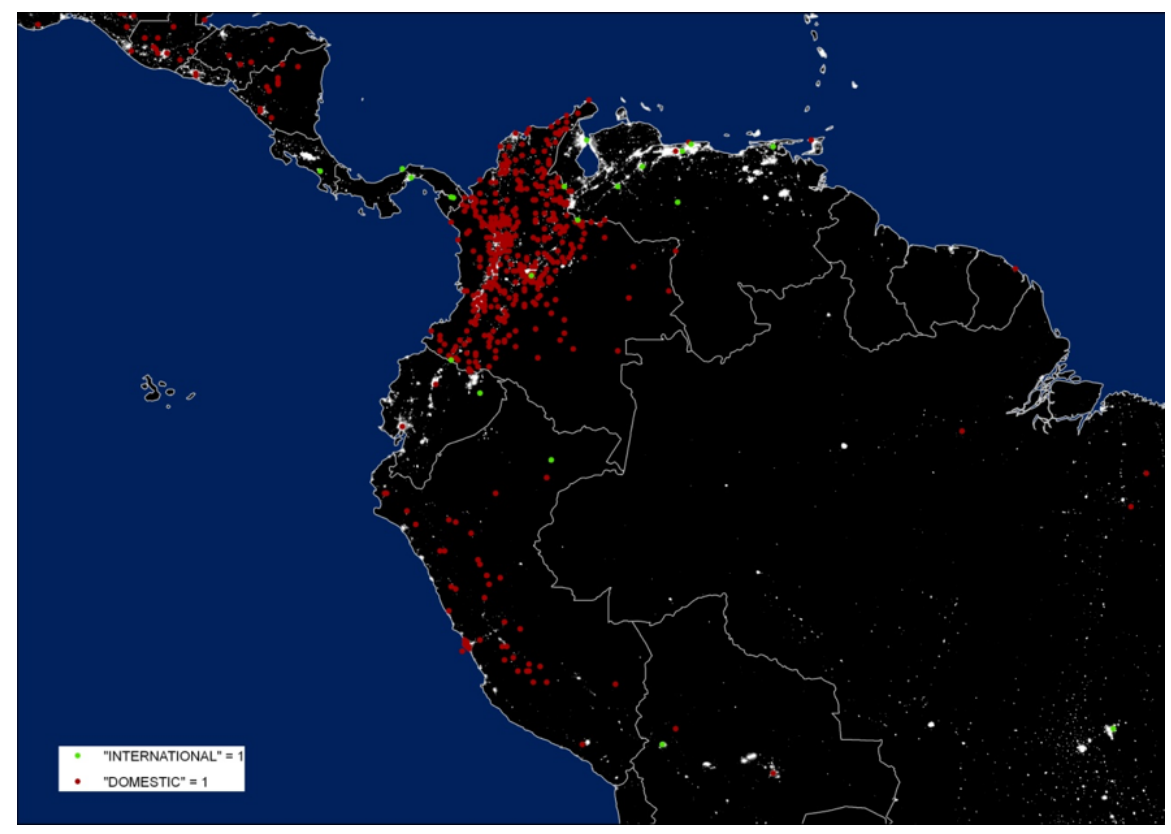

Figure 4: Domestic terrorism (by origin of perpetrators) and nightlight: South America.

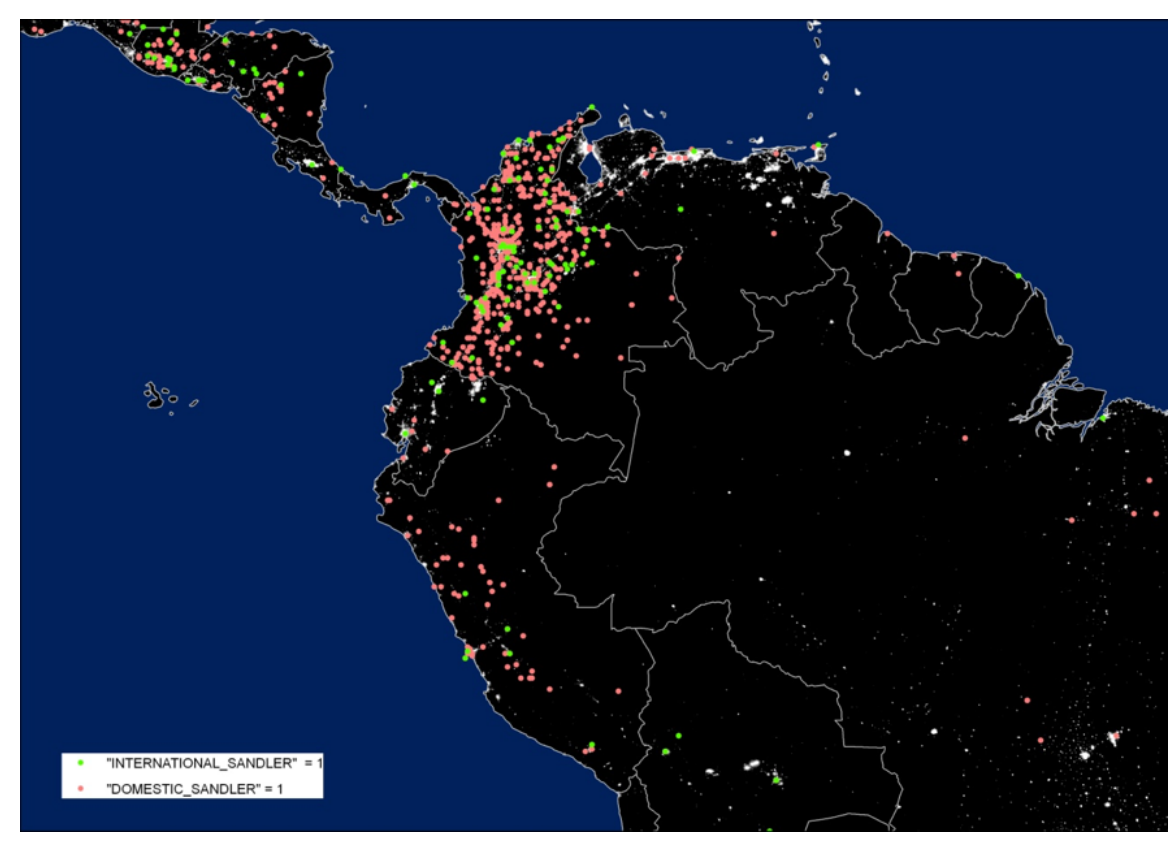

Figure 5: Enders et al.'s (2011) definition of domestic terrorism and nightlight: South America. 


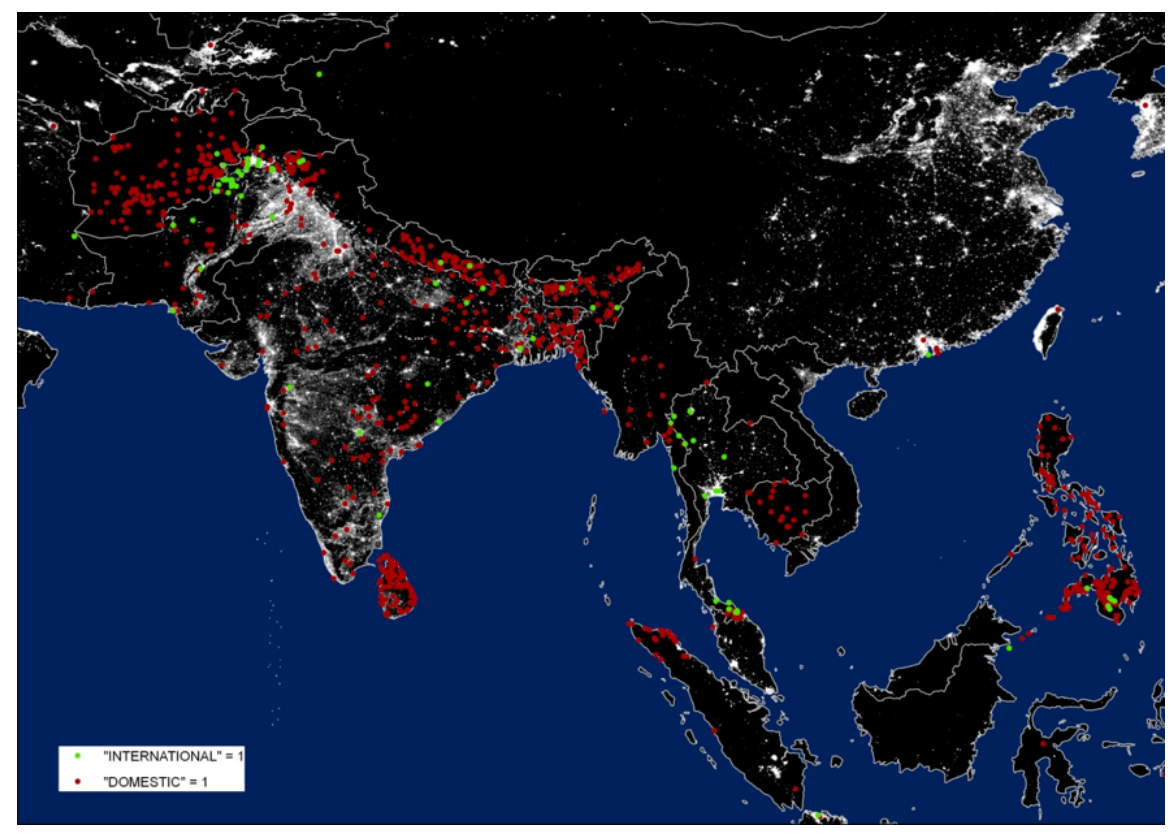

Figure 6: Domestic terrorism (by origin of the perpetrators) and nightlight: South Asia.

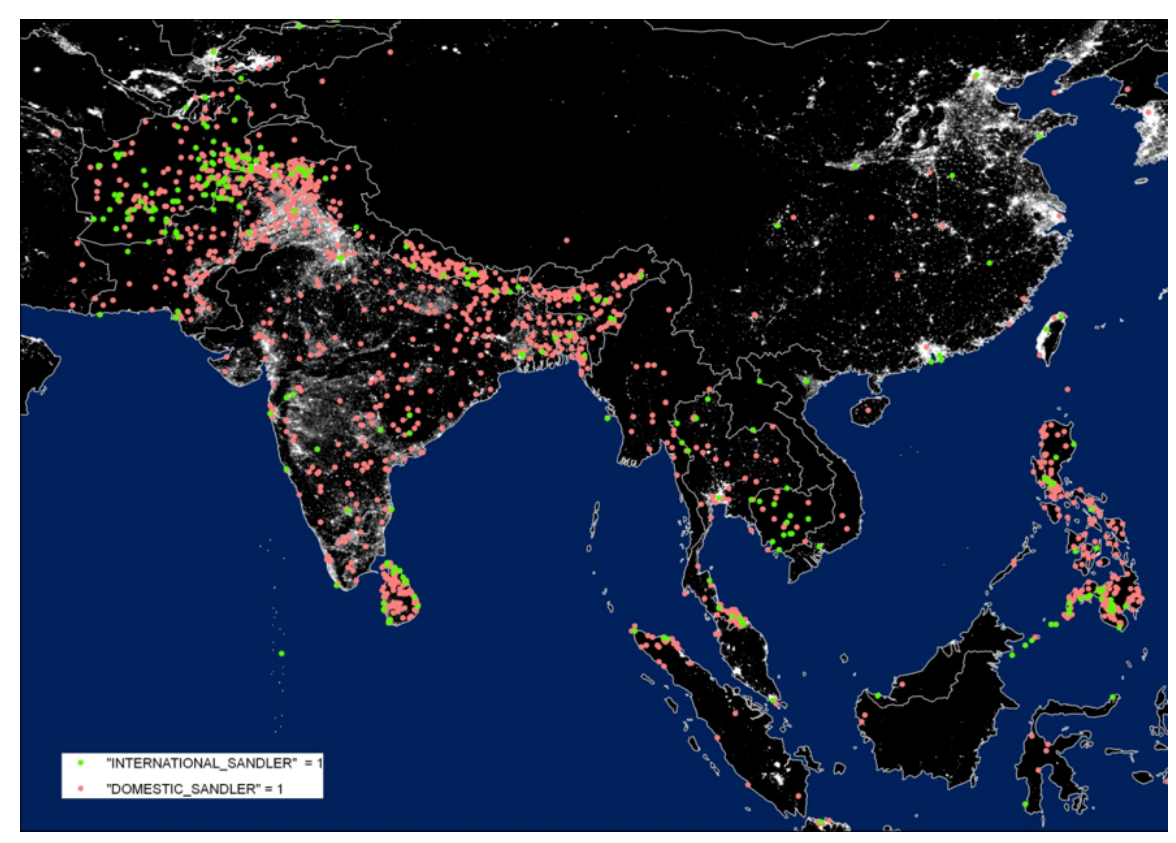

Figure 7: Enders et al.'s (2011) definition of domestic terrorism and nightlight: South Asia. 


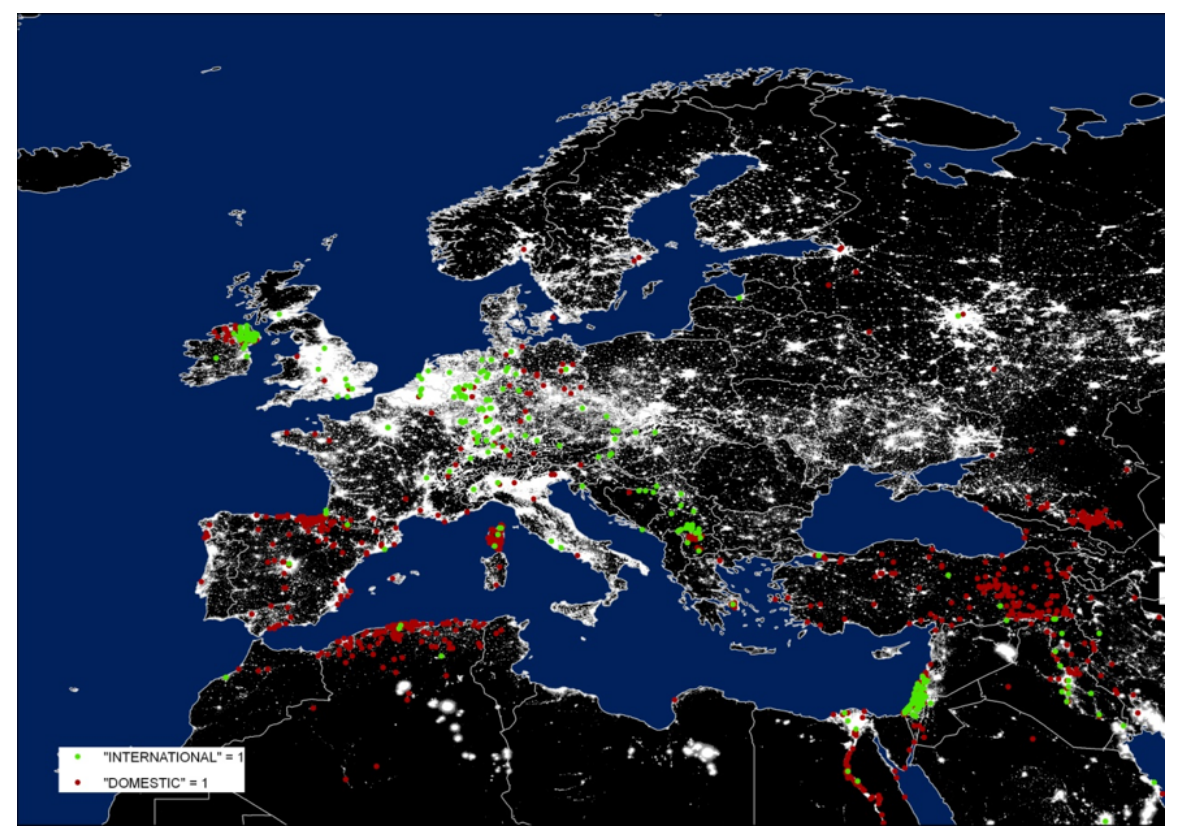

Figure 8: Domestic terrorism (by origin of the perpetrator) and nightlight: Europe.

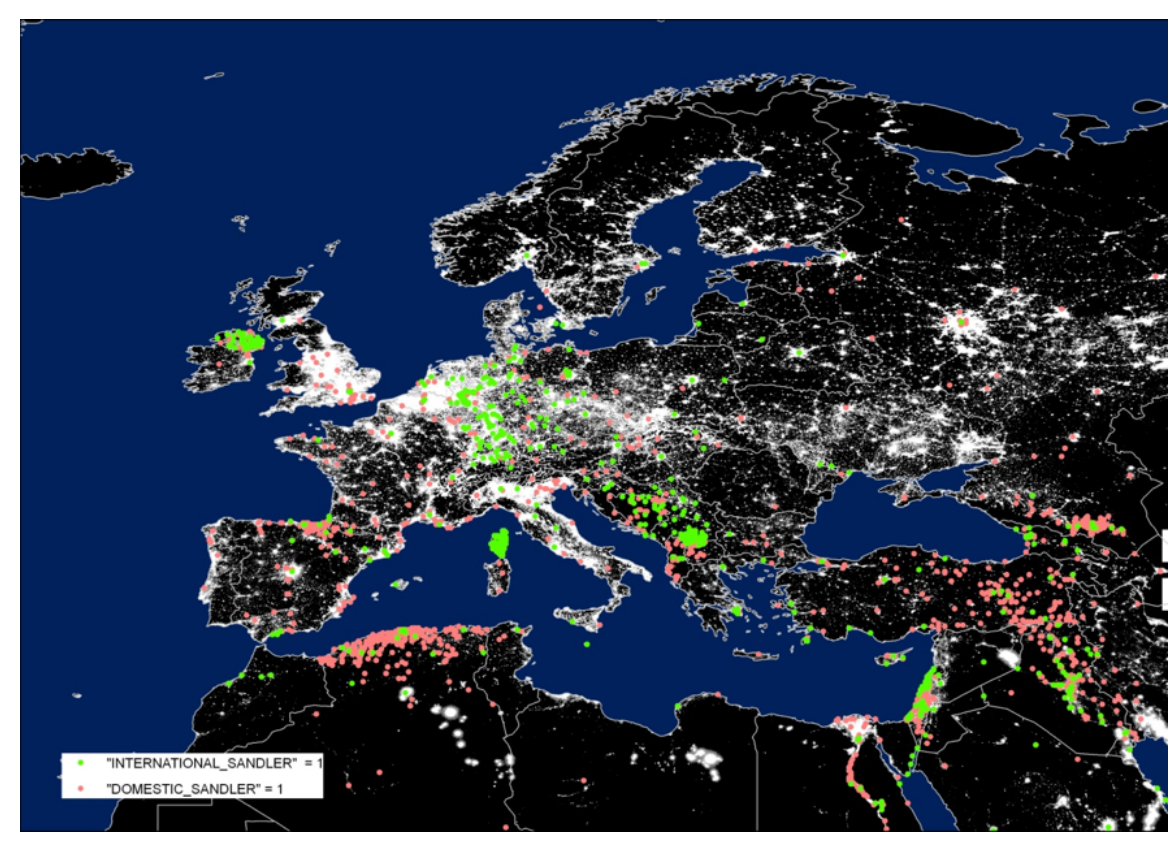

Figure 9: Enders et al.'s (2011) definition of domestic terrorism and nightlight: Europe. 


\section{Notes}

1. Dell (2010) also considers the long-run impact of another institution, the "mita", a forced labor institution used by Spanish rulers of Peru and Bolivia for almost 250 years. Dell (2010) explains mita's persistence through its impact on land tenure (tendency to smallscale farming). Vidal-Robert (2011) analyzes the long-run effects of the Spanish inquisition on current economic performance. He argues that the severity of inquisitorial actions affected entrepreneurial activity and propensity for technological innovation.

2. Recent papers such as Enders et al. (2011) and Nemeth et al. (2014) similarly deal with the definition and analysis of domestic terrorism.

3. While our definition of domestic terrorism is different from than that proposed by Enders et al. (2011), we test for the robustness of the results using their interpretation. We discuss the outcomes in the following pages.

4. Recent exceptions include Nemeth et al. (2014), Findley et al. (2015), and Python et al. (2017).

5. Findley et al. (2015) study the local-level conditions that determine the precise location of transnational terrorist attacks. Similarly, Python et al. (2017) find that high levels of localized ethnic polarization are a significant predictor of a greater number of terrorist attacks.

6. Recent examples include Alesina et al. (2013), Harari \& La Ferrara (2013), Michalopoulos \& Papaioannou (2013), Aragón \& Rud (2013), Maystadt et al. (2014), Berman \& Couttenier (2015), and Berman et al. (2017).

7. Harari \& La Ferrara 2013) propose a different alternative to deal with this issue. They assign uniquely each cell to a particular country; that which covers the largest share of the cell's territory. They include a dummy for these cells among the explanatory variables.

8. In fact, the effect is non-linear with a positive coefficient in the quadratic term.

9. Benjamin et al. (2013) review the literature on the effect of weather on economic outcomes and conflict. The analysis of the determinants of conflict has similarly shifted to high resolution geographical units.

10. See Dal Bó \& Dal Bó (2011), Bazzi \& Blattman 2014), Berman \& Couttenier (2015), and Berman et al. (2017) for more details.

11. Ladner \& Persson 2009).

12. A lack of social infrastructure and popular support led instead to the rapid capture of the perpetrator of the March 11, 2014 terrorist attacks in Madrid. This event is, however, 
considered international terrorism, and is therefore not the object of this investigation.

13. "Legal" terrorists are defined as those with no previous criminal record who provide arms and help hide perpetrators after the terrorist act.

14. Fearon \& Laitin (2003) introduce roughness and altitude as determinants of the likelihood of the onset of civil conflicts. Along similar lines, Gaibulloev (2014) finds that while country elevation positively affects the location decision of a terrorist group, the share of landlocked area operates in the opposite direction.

15. Hsiang et al. (2013) present a meta-analysis of the contributions in this literature.

16. Kelman 2011) raises concerns over Brancati (2007) methodology, noting that the correlation between increased conflict and resource scarcity is provided without a convincing explanation of the causation mechanism.

17. Many papers argue that "creative destruction" can lead to a rapid improvement in economic conditions after a natural disaster. See for instance Loayza et al. (2012).

18. Pages 1 and 2.

19. See Appendix I for the specific procedure used by Enders et al. (2011).

20. As a robustness check, we also construct a second definition of domestic terrorism using the same procedure as Enders et al. (2011).

21. http://www. seismo.ethz.ch/static/GSHAP/

22. http://gmo.gfz-potsdam.de/pub/poster/GSHAP_World_Map_Poster.pdf

23. http://www.ngdc.noaa.gov/

24. The estimates are robust to the use of standard error adjustment for spatial correlation. 


\section{A Appendix}

\section{A.1 Appendix I: The GTD database}

Information in the GTD is drawn entirely from publicly available, opensource materials. These include electronic news archives, existing datasets, secondary source materials such as books and journals, and legal documents. The database developers attempt, to the best of their abilities, to corroborate each piece of information using multiple independent open sources.

The first phase of data collection for the GTD (GTD1: 1970-1997) was carried out by the Pinkerton Global Intelligence Service (PGIS) - a private security agency. Cases that occurred between 1998 and 2007 were identified and coded by the Center for Terrorism and Intelligence Studies (CETIS), in partnership with START (National Consortium for the Study of Terrorism and Responses to Terrorism).

In addition to data originally collected by PGIS and CETIS, other archives and sources on terrorism incidents have also been incorporated, including the Conflict Archive on the Internet (CAIN); the Australian Turkish Media Group; Armenian Terrorism: The Past, Present, the Prospects, by Francis Hyland; the National Abortion Federation; and "Further Submissions and Responses by the ANC to Questions Raised by the Commission for Truth and Reconciliation 12 May 1997."

\section{A.2 Appendix II: Operational definition of a domestic terrorist act}

Enders et al. (2011) use a two-step procedure to identify domestic terrorism as the residual events once international and uncertain events have been extracted from the data.

1. In their first step they thus exclude some observations:

"We begin by excluding observations that do not meet the following three GTD inclusion criteria: (i) the attack is perpetrated for a political, socioeconomic, or religious motive; (ii) the attack is intended to coerce, intimidate, or send a message to a wider audience than the immediate victim(s); and (iii) the attack is beyond the boundaries set by international humanitarian law". (Enders et al., 2011) 
In other words, if all three criteria are not met, the event is excluded.

Following Enders et al. (2011), we also exclude all terrorist incidents that are described as "Doubt Terrorism Proper."

2. Their second step is to construct a definition of transnational events. This has five sub-steps (our own emphasis in bold):

(a) "We examine the nationality of the victims in relation to the venue country. GTD presents nationality information for up to three victims for a given incident. If the venue country is different from the country of nationality for one or more victims, then the attack is clearly a transnational terrorist incident". (Enders et al., 2011)

(b) "Target types are consulted. Attacks against diplomatic targets are deemed to be transnational incidents because they are carried out against foreign missions, including embassies and consulates. Diplomatic targets also include cultural centers that have diplomatic functions. Terrorist attacks against diplomatic staff, their families, and property are transnational in nature, as are attacks against nongovernmental organizations (NGOs), which are multinational entities". (Enders et al., 2011)

(c) "We look at target entities in GTD: terrorist attacks against US entities that occurred outside the USA are classified as transnational terrorist events. Similarly, we code terrorist incidents directed at international entities (e.g. UN agencies or NATO infrastructure) and foreign businesses as transnational terrorism". (Enders et al., 2011)

(d) "We utilize GTD information on US victims, US hostages, and $\boldsymbol{U S}$-specific demands to identify transnational terrorist incidents. A terrorist act that occurs outside of the USA and that involves US fatalities or injuries is classified as transnational. The presence of US hostages in a foreign country also indicates that the terrorist event is transnational. If, in a hostage event outside the USA, a ransom is demanded from or paid by a US source, then the incident is clearly a transnational terrorist incident". (Enders et al. 2011)

(e) "We use GTD information on the country where kidnappings or hijackings concluded. Any such incidents that involve the diversion of an airplane or resolution in another country, so that two 
or more countries are involved, are transnational terrorist events". (Enders et al., 2011)

3. Dummy uncertain: Uncertain events, or those with missing or unknown information regarding nationality, target type, target entity, US fatalities, injuries, hostages, ransom demanded or paid.

4. Dummy domestic new: Domestic are those that are neither transnational nor uncertain. 


\section{B Technical appendix}

All data was obtained from the National Geophysical Data Center, specifically the Earth Observation Group (EOG) reference to the DMSP-OLS Nighttime Lights Time Series version 4 (http://www.ngdc.noaa.gov/). This first study is referenced at satellite F10 - year 1992. From three available image types, we used stable light ranging from values of 1 to 63. Transfer

data: The TAR file was converted in a geotif file. This geotif file was then processed using ArcGISC software and converted into a vectorial file support. The vector form file chosen was ESRIC shapefile. Geotif minimum pixel is over $0.75 \mathrm{~km} 2$.

Data management: Our scope is a database made up of 27,445 observations (see Map A.1). Each observation has a regular area of one square degree. Observations can be grouped in four categories:

1. 24,903 observations belonging to the same country.

2. 2,264 observations belonging to two different countries. The theoretical regular area of one square degree is modified to each country area.

3. 257 observations belonging to three different countries. The theoretical regular area of one square degree is modified to each country area.

4. 21 observations belonging to four different countries. The theoretical regular area of one square degree is modified to each country area.

The aim of this study is to assign data values from nighttime light to each observation under two parameters:

1. Total Nighttime Light by observation.

2. Nighttime Light by $\mathrm{km} 2$ and by observation.

The procedure is across both layers (observations and night time light) and summarizes nighttime light values by observation, by km2, and by observation.

Difficulties: One significant challenge was the magnitude of data processed. In terms of the observations, there are 24,903 enclosures of $\pm 111 \mathrm{~km} 2$ and 2,542 enclosures of different sizes due to a complex system of borders. In terms of nighttime lights, there are more than 9x106 wide range polygons. 
The use of Geographic Information System models allows to intersect both layers, observations, and nighttime light values. Due to database magnitude, the process had to be split into smaller pieces.

Results: Using our working methodology and initial approaches, we obtained a list with total nighttime light by observation and by $\mathrm{km} 2$.

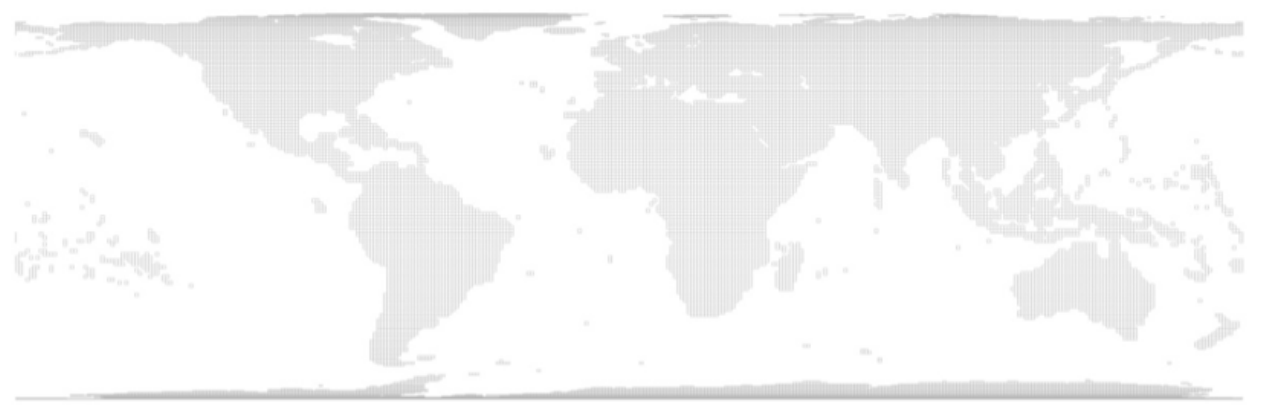

Figure A.1: Vector grid map of the 27,445 observations. 